\title{
Detecting inter-aquifer leakage in areas with limited data using hydraulics and multiple environmental tracers, including ${ }^{4} \mathrm{He}$, ${ }^{36} \mathrm{Cl} / \mathrm{Cl},{ }^{14} \mathrm{C}$ and ${ }^{87} \mathrm{Sr} /{ }^{86} \mathrm{Sr}$
}

\author{
Stacey C. Priestley ${ }^{1}$ - Daniel L. Wohling ${ }^{2}$ - Mark N. Keppel ${ }^{2} \cdot$ Vincent E. A. Post ${ }^{1}$. \\ Andrew J. Love ${ }^{1} \cdot$ Paul Shand ${ }^{1,3} \cdot$ Lina Tyroller ${ }^{4} \cdot$ Rolf Kipfer $^{4,5}$
}

Received: 6 December 2016 / Accepted: 19 May 2017 /Published online: 16 June 2017

(C) The Author(s) 2017. This article is an open access publication

\begin{abstract}
The investigation of regionally extensive groundwater systems in remote areas is hindered by a shortage of data due to a sparse observation network, which limits our understanding of the hydrogeological processes in arid regions. The study used a multidisciplinary approach to determine hydraulic connectivity between the Great Artesian Basin (GAB) and the underlying Arckaringa Basin in the desert region of Central Australia. In order to manage the impacts of groundwater abstraction from the Arckaringa Basin, it is vital to understand its connectivity with the GAB (upper aquifer), as the latter supports local pastoral stations and groundwaterdependent springs with unique endemic flora and fauna. The study is based on the collation of available geological information, a detailed analysis of hydraulic data, and data on environmental tracers. Enhanced inter-aquifer leakage in the centre of the study area was identified, as well as recharge to the GAB from ephemeral rivers and waterholes. Throughout the rest of the study area, inter-aquifer leakage is likely
\end{abstract}

Electronic supplementary material The online version of this article (doi:10.1007/s10040-017-1609-x) contains supplementary material, which is available to authorized users.

Stacey C. Priestley

stacey.priestley@flinders.edu.au

1 School of the Environment, Earth Sciences Building, Flinders University, Bedford Park, SA 5042, Australia

2 Department of Environment, Water and Natural Resources, Government of South Australia, Adelaide, SA 5000, Australia

3 CSIRO Land and Water, Urrbrae, SA 5064, Australia

4 Swiss Federal Institute of Aquatic Science and Technology (Eawag), 8600 Duebendorf, Switzerland

5 Institute of Geochemistry and Petrology, Swiss Federal Institute of Technology (ETH), 8092 Zurich, Switzerland controlled by diffuse inter-aquifer leakage, but the coarse spatial resolution means that the presence of additional enhanced inter-aquifer leakage sites cannot be excluded. This study makes the case that a multi-tracer approach along with groundwater hydraulics and geology provides a tool-set to investigate enhanced inter-aquifer leakage even in a groundwater basin with a paucity of data. A particular problem encountered in this study was the ambiguous interpretation of different age tracers, which is attributed to diffusive transport across flow paths caused by low recharge rates.

Keywords Australia - Aquitard · Arid regions ·

Hydrochemistry · Inter-aquifer leakage/cross formational flow

\section{Introduction}

The sustainable management of groundwater resources requires understanding of the water flows between aquifers (Alley et al. 2002; Hiscock et al. 2002). Failing to take into account inter-aquifer leakage in the analysis of regional-scale flow systems can lead to significant errors in the estimation of flow rates in aquifers (Freeze and Witherspoon 1967; Love et al. 1996; Tóth 2009). There has been increased interest in inter-aquifer leakage mechanisms in recent times because of the exploration for and development of coal seam and shale gas resources and the associated risk of groundwater contamination (Myers 2012; Vidic et al. 2013; Brantley et al. 2014; Field et al. 2014).

Laterally extensive aquitards that have no preferential flow pathways are the major control to separate aquifers (Cherry and Parker 2004), but even in tight aquitards there is always a small amount of diffuse leakage through the aquitard pore spaces (Cherry and Parker 2004). The volumetric flow across the aquitard from diffuse leakage can be a significant 
component of the water balance over large areas (Cherry and Parker 2004; Konikow and Neuzil 2007). The presence of preferential pathways enhances the rate of water movement through an aquitard causing enhanced inter-aquifer leakage (Neuzil 1994; Hendry et al. 2004; Hart et al. 2006; Myers 2012). Such preferential pathways can be faults, intercalations of higher permeability sediments, or thinner aquitard sections (Cherry and Parker 2004). Zones of enhanced inter-aquifer leakage can have a disproportional contribution to the water balance relative to their size. Bredehoeft et al. (1983) found that $25 \%$ of groundwater discharged from the Dakota groundwater system is enhanced inter-aquifer leakage through faults from the aquifer below. The difficulty to quantify inter-aquifer leakage at a regional scale is that diffuse inter-aquifer leakage rates are often so small that they are very hard to detect and quantify, although they can result in a large volumetric flow. Localised enhanced inter-aquifer leakage with high fluxes can easily be missed at the spatial resolution of regional surveys.

The direction of inter-aquifer leakage can be determined by hydraulic head differences between aquifers (Dogramaci et al. 2001; Arslan et al. 2015), but this can be complicated when groundwater flow is affected by variations in water density (Post et al. 2007). The rates of diffuse leakage through aquitards can in principle be calculated if an appropriate vertical hydraulic conductivity is known $\left(K_{\mathrm{V}}\right)$. Generally, $K_{\mathrm{V}}$ values measured from aquitard core samples are used, although they have been found to be consistently lower than regional-scale $K_{\mathrm{V}}$ values, as the latter incorporate both diffuse and preferential leakage (van der Kamp 2001; Smerdon et al. 2014; Batlle-Aguilar et al. 2016).

Environmental tracers can be used as indicators for enhanced inter-aquifer leakage and mixing in regional groundwater investigations (Glynn and Plummer 2005; Sanford et al. 2011). Clear contrasts in the environmental tracer concentrations (or ratios expressing the relative abundance of isotopes) between aquifers indicate where there is little vertical flow, whereas similar environmental tracer concentrations may be an indication of mixing or enhanced inter-aquifer leakage. For example, major and trace element concentration data were used to demonstrate enhanced inter-aquifer leakage within the Galilee Basin, Australia (Moya et al. 2015) and the Yarkon-Taninim basin, Israel (Zilberbrand et al. 2014). Vertical leakage between the Continental and Djeffara aquifer system in Tunisia through a fault was identified and quantified using stable isotopes of water (Trabelsi et al. 2009). Additionally, groundwater mixing and locations of enhanced inter-aquifer leakage have been identified by ${ }^{87} \mathrm{Sr} /{ }^{86} \mathrm{Sr}$ ratios and other tracers such as $\delta^{34} \mathrm{~S}$ and $\delta^{18} \mathrm{O}$ values of $\mathrm{SO}_{4}$ or $\delta^{13} \mathrm{C}$ in the Murray Basin, Australia (Dogramaci et al. 2001; Dogramaci and Herczeg 2002) and Adour-Garonne district, France (Brenot et al. 2015).

For simple flow systems with little mixing, decaying age tracers such as ${ }^{14} \mathrm{C}$ and ${ }^{36} \mathrm{Cl} / \mathrm{Cl}$, decrease along the flow path, while accumulating tracers such as ${ }^{4} \mathrm{He}$, increase along the flow path. Such regular patterns can be disrupted by the localised introduction of different age water. Age tracers used in combination with major and trace elements (Herczeg et al. 1996), stable isotopes of water (Love et al. 1993), as well as ${ }^{87} \mathrm{Sr} /{ }^{86} \mathrm{Sr}$ ratios and $\delta^{13} \mathrm{C}$ (Cartwright et al. 2012) have provided evidence for locations of inter-aquifer leakage and hydrochemical evolution within the Otway Basin and the Murray Basin, Australia.

Due to their conservative nature, noble gases are also useful tracers to analyse for inter-aquifer leakage (Kipfer et al. 2002). Measurements of noble gases, stable isotopes of water, $\mathrm{Cl}$ and ${ }^{14} \mathrm{C}$ provided evidence for localised downward leakage of shallow groundwater in the Upper Floridan aquifer system, USA (Clark et al. 1997). ${ }^{3} \mathrm{H} /{ }^{3} \mathrm{He}$ ratios in combination with major ion geochemical reaction modelling were used to determine downward leakage into the Memphis aquifer, USA (Larsen et al. 2003). Upward inter-aquifer leakage in the vicinity of faults has been identified by radiogenic ${ }^{4} \mathrm{He}$ in the Lower Rhine Embayment, Germany (Gumm et al. 2016) and by ${ }^{3} \mathrm{He} /{ }^{4} \mathrm{He}$ ratios in the Kazan Basin, Turkey (Arslan et al. 2015). For the Paris Basin, Marty et al. (2003) demonstrated with ${ }^{3} \mathrm{He}$ concentrations that diffusive mass transfer across a major aquitard was negligible, implying that groundwater moves along a major fault.

This study focusses on the connectivity between the Great Artesian Basin (GAB) and underlying Arckaringa Basin, located in central Australia (Fig. 1b). The GAB is one of the largest aquifer systems in the world, and has been the subject of numerous investigations, which focused largely on the eastern artesian and north-western sections of the basin (Habermehl 1980; Herczeg et al. 1991; Love et al. 2000, 2013; Mahara et al. 2009; IESC 2014; Moya et al. 2015). Few studies focused on the unconfined south-western part of the GAB, but some have highlighted the potential connectivity between the GAB and the Arckaringa Basin (Smerdon et al. 2012; Keppel et al. 2015). There are currently numerous proposals for exploration and mining of coal and gas in the Arckaringa Basin (Wohling et al. 2013). Because of the associated risk of groundwater contamination from coal seam and shale gas extraction via fracking, it is vital to investigate potential inter-aquifer leakage mechanisms (Myers 2012; Vidic et al. 2013); however, the scarcity of observation points hampers an understanding of inter-aquifer leakage processes, and the groundwater system more generally.

A major challenge encountered in hydrogeological investigations in sparsely developed areas such as the Arckaringa Basin is the scarcity of data (Melloul 1995; Cudennec et al. 2007; Masoud et al. 2013; Candela et al. 2014). Whilst drilling additional observation wells is the only real solution to this problem, prohibitive costs, as well as access and time constraints, often render this intractable. Accepting that the number of observation points is fixed, increasing the information 
Fig. 1 a Map of the extent and generalised groundwater flow paths of the upper aquifer and lower aquifer. The upper aquifer density-corrected freshwater potentiometric surface is also included. An approximate 'discharge line' is shown by a reddashed line for both upper and lower aquifers. The study area shown by the red box includes the majority of the wells completed in the lower aquifer and is $\sim 14,000 \mathrm{~km}^{2}$ in area. b Full Great Artesian Basin (GAB) and underlying Arckaringa basin extents

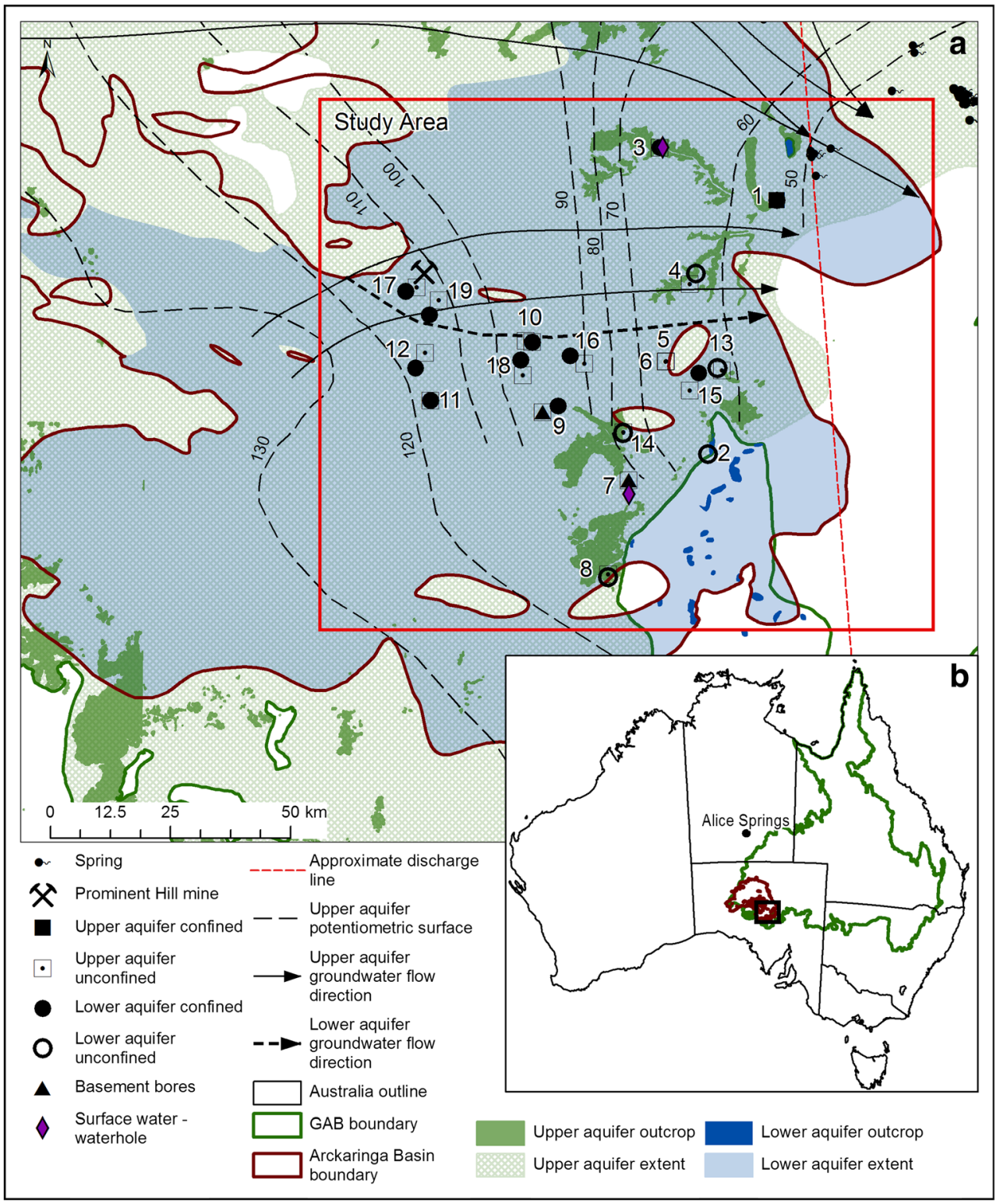

content at each location may address the problem to some extent (Melloul 1995). The present study therefore adopted a comprehensive multidisciplinary approach based on the aforementioned techniques and had the objective to assess if, and which, combinations of methods are best suited to improve the regional-scale understanding of the system when the spatial data density is low. The usefulness of each of the individual investigation methods, and combinations thereof, will be assessed and evaluated.

\section{Site description}

The GAB and Arckaringa Basin are underlain by ProterozoicArchean crystalline metasediment, limestone and igneous rocks, which are colloquially referred to as 'basement'
(Ambrose and Flint 1980). The GAB contains JurassicCretaceous sedimentary rocks, whereas the Arckaringa Basin comprises older Carboniferous-Permian sedimentary rocks. Glacial scouring during the Devonian-Carboniferous and faulting during the Early Permian has resulted in the formation of troughs and sub-basins (Wohling et al. 2013). Compression and uplift events at approximately $50 \mathrm{Ma}$ and 15-5 Ma have caused further deformation of CarboniferousPermian sediments (Wohling et al. 2013).

The main GAB aquifer units within the study area (Fig. 1a) are the Cadna-owie Formation and Algebuckina Sandstone which are hydraulically connected in the western margin of the GAB and are thus treated as one aquifer (Love et al. 2013), which will be referred to as the 'upper aquifer' in this study. The upper aquifer is approximately $20 \mathrm{~m}$ thick in the study area with measured hydraulic conductivity measurements 
Fig. 2 Hydrogeological transect following the generalised groundwater flow path in the lower aquifer (Fig. 1a). Schematic depiction of variation in environmental tracers in the lower aquifer from enhanced inter-aquifer leakage of upper aquifer water (young/fresh groundwater) as described in conceptual model 2

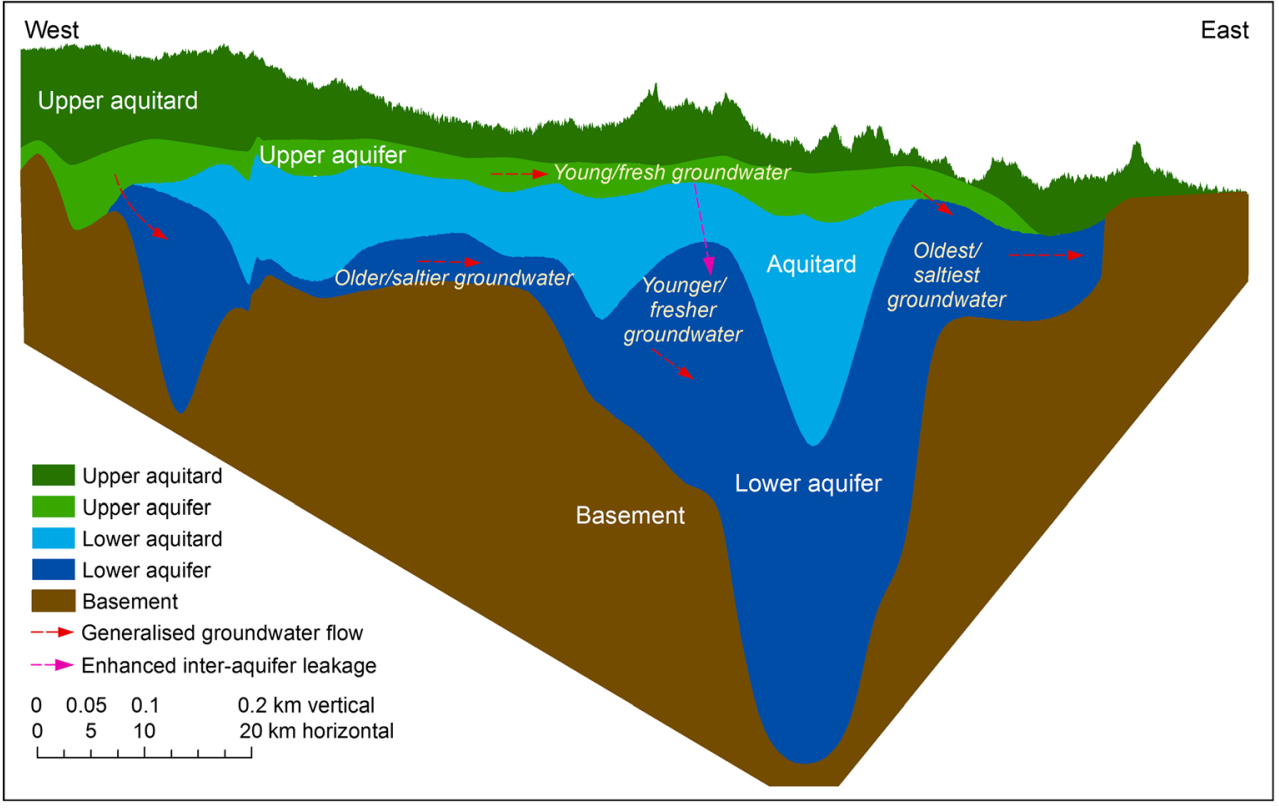

$>10 \mathrm{~m} /$ day (Keppel et al. 2013) and water levels ranging from 130 to $50 \mathrm{~m} \mathrm{AHD}$-Fig. S1a of the electronic supplementary material (ESM). The upper aquifer is confined by the Bulldog Shale, except near the south-western and eastern margin of the Arckaringa Basin, where the aquifer crops out and is unconfined (Fig. 1a). The Bulldog Shale, referred to as the 'upper aquitard', is a marine mudstone aquitard with vertical conductivity measurements of $10^{-14}-10^{-13} \mathrm{~m} / \mathrm{s}$; hence, it is inferred that any significant inter-aquifer leakage is via preferential flow paths (Keppel et al. 2013). The main aquifer in the Arckaringa Basin in the study area is the Boorthanna Formation, a marine and glacial sandstone and diamictite, which will be referred to as the 'lower aquifer'. The lower aquifer average thickness is $50 \mathrm{~m}$ in the study area with measured hydraulic conductivity measurements from 1 to $5 \mathrm{~m} /$ day (Wohling et al. 2013) and water levels range from 130 to $60 \mathrm{~m}$ AHD (Fig. S1b of the ESM). The lower aquifer only crops out along the south-eastern margin of the Arckaringa Basin (Fig. 1a). The upper and lower aquifers are separated by an aquitard formed by mudstones, siltstones and shales of the Stuart Range Formation throughout most of the basin; it is here referred to as the 'lower aquitard' (Fig. 2). In the study area the lower aquitard average thickness is $70 \mathrm{~m}$ with aquitard core hydraulic conductivity measurements between $10^{-10}$ to $10^{-13} \mathrm{~m} / \mathrm{s}$ (Kleinig et al. 2015).

The climate of the study area is arid; precipitation is extremely variable, both temporally and spatially. The long-term average annual precipitation rate is estimated to be $120 \mathrm{~mm} / \mathrm{yr}$ (Allan 1990; McMahon et al. 2005). The upper aquitard inhibits recharge to the underlying aquifers, which is estimated by Love et al. (2013) to be $<0.25 \mathrm{~mm} / \mathrm{yr}$. Higher recharge rates occur in areas with ephemeral rivers where the aquifer crops out or is close to the surface (Love et al. 2013). Within the study area groundwater flow in the upper aquifer is from the (south)west toward the east (Love et al. 2013). In the eastern margin, where the upper and lower aquifers come into contact (i.e. the lower aquitard is absent; Fig. 2), groundwater potentially discharges into the lower aquifer and then into the basement (Fig. 1a), whereas in the north-eastern section of the study area, the Arckaringa Basin groundwater discharges upward to the springs (Fig. 1a).

The lower aquifer outcrop extent is limited so recharge is most likely to occur from the upper aquifer. Vertical flow from the upper to the lower aquifer is estimated to be between 0.05 and $0.5 \mathrm{~mm} / \mathrm{yr}$ and likely to be an important component of the water balance (Keppel et al. 2015). In the southern margin, recharge could occur where the aquifer crops out or is close to the surface below ephemeral rivers (Keppel et al. 2015). Given the lack of wells completed in the lower aquifer, this study focused on the area with the most wells available (Fig. 1a). The Prominent Hill mine has been extracting groundwater from the lower aquifer from these wells since 2006 (SKM 2010).

\section{Methods}

Published geological information, including interpreted elevation top of aquifers and aquitards, as well as aquifer isopachs (Sampson et al. 2012a, b, 2015) and fault locations (Ambrose and Flint 1980; Cowley and Martin 1991; Drexel and Preiss 1995), were used to identify zones that may potentially be associated with enhanced vertical permeability. Where the thickness of the aquitard is lower, resistance to vertical flow 
is also reduced. This effect is expressed by the hydraulic resistance (Eq. 1)

$c=\frac{b}{K_{\mathrm{v}}}$

where $c$ is the hydraulic resistance [T], $b$ the aquitard thickness where present, or vertical distance $\left(z_{2}-z_{1}\right)$ where the aquitard is absent [L] and $K_{\mathrm{V}}$ the vertical hydraulic conductivity of the aquitard [L/T]. $K_{\mathrm{V}}$ values in the study area were measured on core samples obtained from a borehole drilled alongside well couplet 11 in March 2015 (Kleinig et al. 2015). The upper aquifer samples comprise medium-to-coarse-grained sand sequences that had an average measured $K_{\mathrm{V}}$ of $2 \times 10^{-7} \mathrm{~m} / \mathrm{s}$ from two samples $\left(6 \times 10^{-6}-1 \times 10^{-8} \mathrm{~m} / \mathrm{s}\right)$. The lower aquitard samples are variable grey and brown consolidated claystone samples with thin $(<50 \mathrm{~mm})$ sandstone interbeds and gradational sequences that had an average measured $K_{\mathrm{V}}$ of $5 \times 10^{-12} \mathrm{~m} / \mathrm{s}$ from eight samples $\left(4 \times 10^{-10}-4 \times 10^{-13} \mathrm{~m} /\right.$ s). A lower aquifer sample grey sandstone with poorly sorted sand and moderate percentage of clay had a measured $K_{\mathrm{V}}$ of $5 \times 10^{-11} \mathrm{~m} / \mathrm{s}$ (Kleinig et al. 2015), although other $K_{\mathrm{V}}$ estimates between $1 \times 10^{-5}-5 \times 10^{-5} \mathrm{~m} / \mathrm{s}$ are more representative of the lower aquifer (Wohling et al. 2013).

The second step involved a detailed analysis of the hydraulics within the two aquifers. This included preparation of preexploitation freshwater head contour maps (Bachu 1995) and vertical head gradients across the aquitard to determine potential vertical flow direction. No multi-level observation wells were present in the study area, so well couplets were selected by matching wells in the upper and lower aquifers that are located within $4 \mathrm{~km}$ of each other. Additionally, time series of hydraulic head in the upper aquifer were analysed to detect a response to Prominent Hill mine groundwater extraction from the lower aquifer, which would indicate enhanced inter-aquifer connectivity (Neuman and Witherspoon 1972).

If hydraulic resistance $(c)$ is known, the rate of diffuse interaquifer leakage can be estimated. The analysis needs to take into account the difference in groundwater density due to variations in salinity or temperature of the groundwater (Post et al. 2007). Using a freshwater head formulation, the vertical Darcy flux $\mathrm{q}_{\mathrm{z}}$ can be calculated using (Post et al. 2007):

$$
\begin{aligned}
q_{\mathrm{z}} & =-\frac{1}{c}\left[\Delta h_{\mathrm{f}}+b\left(\frac{\rho_{\mathrm{a}}-\rho_{\mathrm{f}}}{\rho_{\mathrm{f}}}\right)\right] \\
& =-K_{\mathrm{v}}\left[\frac{\Delta h_{\mathrm{f}}}{b}+\left(\frac{\rho_{\mathrm{a}}-\rho_{\mathrm{f}}}{\rho_{\mathrm{f}}}\right)\right]
\end{aligned}
$$

where $K_{\mathrm{V}}$ is the vertical hydraulic conductivity [L/T], $\Delta h_{\mathrm{f}}=h_{\mathrm{f}, \mathrm{u}}-h_{\mathrm{f}, \mathrm{l}}$, with $h_{\mathrm{f}, \mathrm{u}}$ and $h_{\mathrm{f}, 1}[\mathrm{~L}]$ being the freshwater head in the upper aquifer and lower aquifer, respectively, $b$ the aquitard thickness where present, or vertical distance $\left(z_{2}-\right.$ $\left.z_{1}\right)$ where the aquitard is absent $[\mathrm{L}]$ and $\left(\rho_{\mathrm{a}}-\rho_{\mathrm{f}}\right) / \rho_{\mathrm{f}}$ the term that represents the relative density contrast, which accounts for the buoyancy effect on vertical flow, in which $\rho_{\mathrm{f}}$ is the freshwater density and $\rho_{\mathrm{a}}$ the average density of groundwater across the aquitard $\left[\mathrm{M} / \mathrm{L}^{3}\right]$ calculated using functions in McCutcheon et al. (1993).

It follows from Eq. (2) that a high $\Delta h_{\mathrm{f}}$ only indicates high flow when $c$ is low. In other words, a large hydraulic head difference between the aquifers can indicate that there is an effective barrier against diffuse flow between aquifers $(c$ is high), and small head gradients can reflect high rates of diffuse inter-aquifer leakage when $c$ is low. In essence, hydraulics provides the direction of inter-aquifer leakage and estimates of diffuse inter-aquifer leakage, but to ascertain if enhanced inter-aquifer leakage is occurring, it is necessary to consider environmental tracers. Here, major and trace elements, stable isotopes of water, $\delta^{13} \mathrm{C}$ and ${ }^{87} \mathrm{Sr} /{ }^{86} \mathrm{Sr}$ ratios were considered. These tracers have been found to be useful to determine the location and proportion of mixing and inter-aquifer leakage in previous studies (Dogramaci and Herczeg 2002; Trabelsi et al. 2009; Zilberbrand et al. 2014). In addition, the age tracers ${ }^{14} \mathrm{C}$, ${ }^{36} \mathrm{Cl} / \mathrm{Cl}$ and radiogenic ${ }^{4} \mathrm{He}$ were analysed; the latter was interpreted in combination with ${ }^{3} \mathrm{He} /{ }^{4} \mathrm{He}$ ratios.

Approximately 130 wells are recorded as being completed in the lower aquifer with the majority $(>90 \%)$ concentrated in the south-eastern Arckaringa Basin clustered in the Prominent Hill mine well fields (Fig. S1b of the ESM). There are only approximately 40 wells completed in the upper aquifer in the same location (Fig. S1a of the ESM). Well couplets were preferentially selected for sampling along a north-west to south-east transect along the regional groundwater flow direction. Groundwater samples were collected from pastoral production and monitoring wells within the upper aquifer as well as mining monitoring wells within the lower aquifer in November 2013 and May 2014. A total of 26 groundwater samples were collected and a list is provided in Table S2 of the ESM; detailed explanations of sampling and analytical methods are also provided in the ESM.

Two possible conceptual groundwater flow models were developed for the study area - in the first model (model 1), there is no enhanced inter-aquifer leakage (e.g. the extremely tight aquitard only allows diffuse inter-aquifer leakage at low flow rates); however, in the second model (model 2), there is concentrated enhanced inter-aquifer leakage via localised secondary features having higher permeabilities.

Model 1 represents an idealised case where radiogenic ${ }^{4} \mathrm{He}$ concentrations increase and the ${ }^{14} \mathrm{C}$ and ${ }^{36} \mathrm{Cl} / \mathrm{Cl}$ decrease along the inferred flow paths. Moreover, provided that ${ }^{87} \mathrm{Sr} /{ }^{86} \mathrm{Sr}$ ratios, $\delta{ }^{13} \mathrm{C}$ values and other environmental tracer concentrations, or isotope ratios, are distinctly different in both aquifers, environmental tracer concentrations, or isotope ratios, are likely to remain different in this model. When water-rock-gas interactions also affect environmental tracers, they need to be taken in to consideration. In model 2, mixing 
Fig. 3 Lower aquitard extent and thickness highlighted with colour variations, interpreted faults and the locations of well couplets with hydraulic data. The leakage rates (m/yr) are calculated using $K_{\mathrm{V}}=5 \times 10^{-12} \mathrm{~m} / \mathrm{s}$ for the lower aquitard and $K_{\mathrm{V}}=2 \times 10^{-7} \mathrm{~m} / \mathrm{s}$ for the upper aquifer (Kleinig et al. 2015) and pre-pumping density-corrected freshwater heads. The range of leakage rates are indicated by colour variations. The hydraulic resistance $(c)$ are labelled in years above the well couplets with the well couplet number also labelled

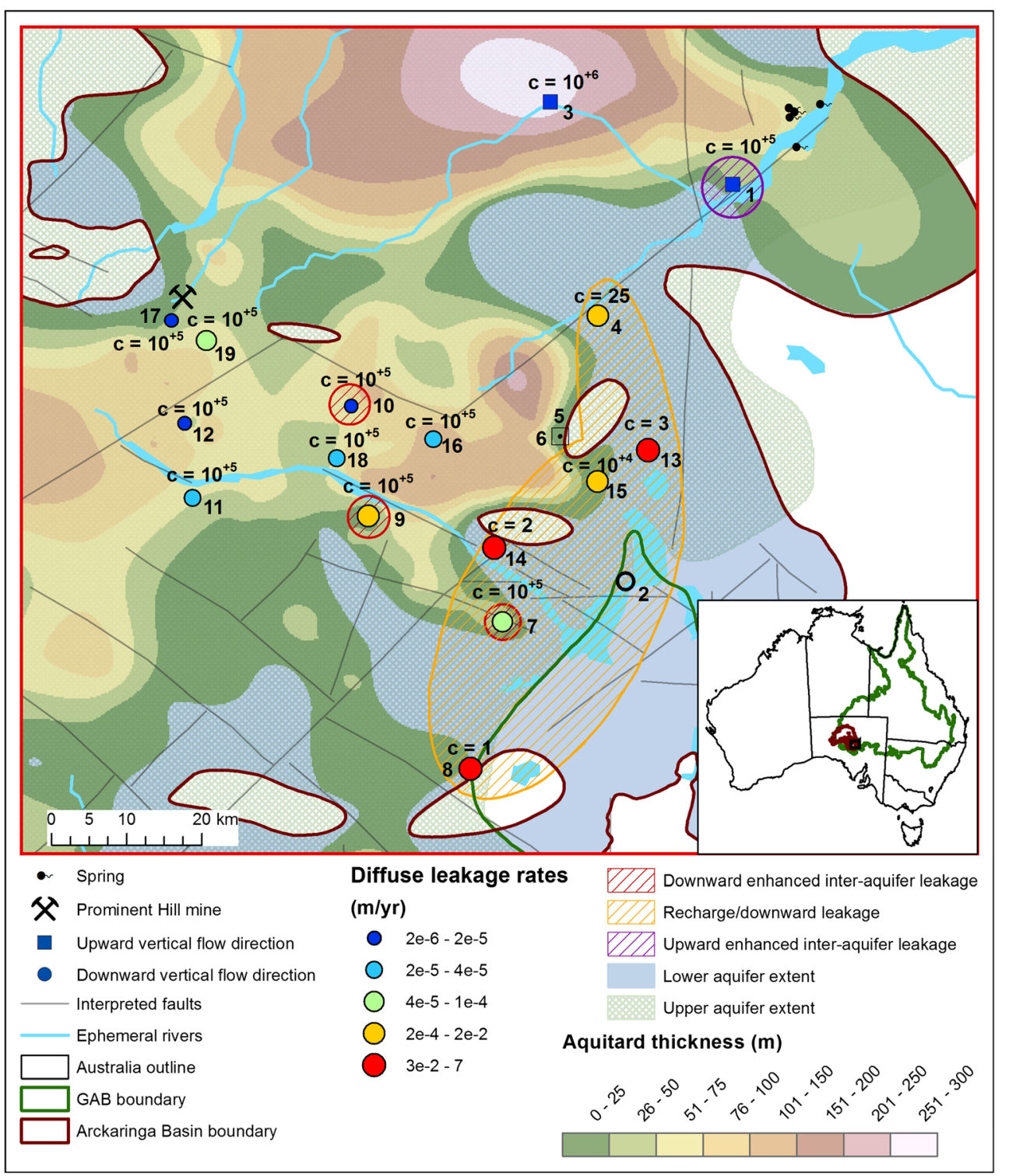

and enhanced inter-aquifer leakage cause variation in groundwater residence time from the idealised system with increasing groundwater residence time (Goode 1996; Bethke and Johnson 2008). Therefore, spatially irregular variations in age tracers (radiogenic ${ }^{4} \mathrm{He},{ }^{14} \mathrm{C}$ and ${ }^{36} \mathrm{Cl} / \mathrm{Cl}$ ) and overlap in environmental tracer concentrations, or isotope ratios, due to enhanced inter-aquifer leakage is expected (see Fig. 2 for schematic depiction).

\section{Results}

\section{Hydrogeology}

The map of lower aquitard thickness and interpreted tectonic features (Fig. 3) shows that the lower aquitard can be up to $300 \mathrm{~m}$ thick. It becomes thinner toward the margins of the aquitard, where it pinches out, and has an average thickness of $70 \mathrm{~m}$. The hydraulic resistance ( $c$; Eq. 1) is included in Fig. 3 , and is highest $\left(10^{+4}-10^{+6}\right.$ years $)$ wherever the aquitard is present, highlighting areas of reduced diffuse inter-aquifer leakage through the aquitard. The hydraulic resistance reduces considerably $(<25$ years $)$ where the aquifers are in contact.

Pre-pumping freshwater head contour map of the lower aquifer indicates groundwater flows from the northwest toward the eastern margin of the study area (Fig. 1a and Fig. S1b of the ESM). A clear recharge area for the lower aquifer could not be delineated due to the limited number and distribution of observation wells outside of the Prominent Hill well fields in the Arckaringa Basin (Fig. S1b of the ESM). Groundwater flow directions in the upper and lower aquifers are similar, with discharge to the basement where the aquifers terminate indicated on Fig. 1a and Figs. S1 of the ESM, near the eastern margin of the lower aquifer. 


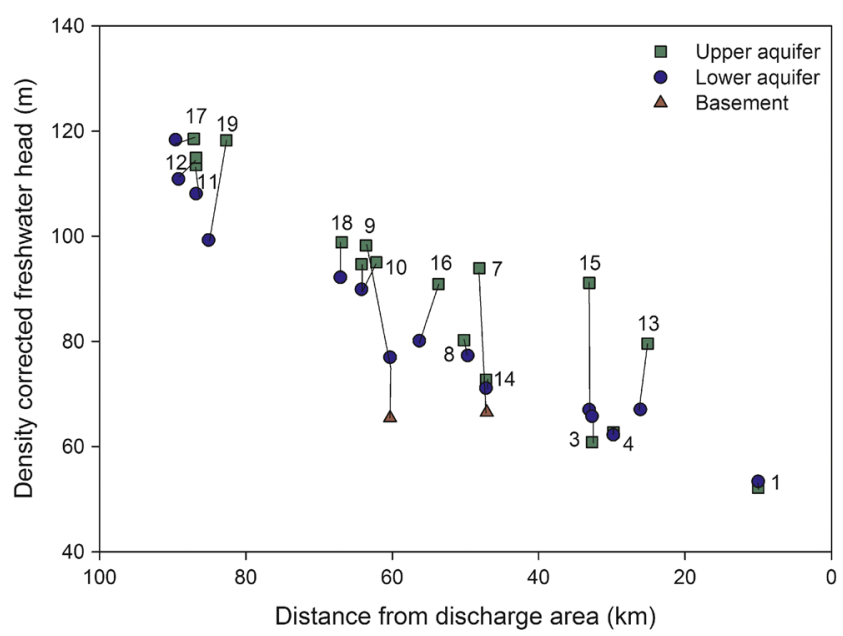

Fig. 4 Pre-pumping density corrected freshwater heads of the well couplets transposed onto a transect from the approximate discharge line, where zero represents the discharge line shown in Fig. 1a and numbers represent the well couplets

The well couplet hydraulic head measurements were corrected to freshwater hydraulic heads using measured temperature and total dissolved solid concentrations (Table S1 of the ESM). The freshwater heads of the well couplets are plotted along the regional head gradient to determine the direction of inter-aquifer leakage (Fig. 4). The density correction can be significant, especially where there are high salinities in the lower aquifer (up to $46 \mathrm{~g} / \mathrm{L}$ leading to head correction terms of up to $2.5 \mathrm{~m}$; Table $\mathrm{S} 1$ of the ESM). The range in groundwater density $\left(\rho_{\mathrm{a}}\right)$ across the aquitard and measured $K_{\mathrm{V}}$ were used to calculate diffuse inter-aquifer leakage flow rates (Eq. 2; Post et al. 2007). The buoyancy term in Eq. (2) was about an order of magnitude less than the freshwater hydraulic gradient, so the latter can be taken as an indicator of the flow direction. The majority of the well couplets showed downward leakage from the upper aquifer to the lower aquifer. However, there is evidence for upward leakage at well couplet locations 1 and 3; shown with slightly higher density corrected freshwater heads in the lower aquifer compared to the upper aquifer (Fig. 4). The calculated diffuse leakage rates through the lower aquitard were $<1 \mathrm{~mm} / \mathrm{yr}$, but higher rates were calculated where it is thin or absent (up to $7 \mathrm{~m} / \mathrm{yr}$ ) (Fig. 3).

Pumping in the lower aquifer since 2006 has caused drawdowns of up to $30 \mathrm{~m}$ in the lower aquifer (Fig. 5; Richards 2013). Time series well couplet hydraulic head data in the upper and lower aquifers were compared to locate enhanced inter-aquifer connectivity, with well couplet 10 and 18 time series data plotted in Fig. 5. There are no drawdowns observed in the upper aquifer except for well U10b in the upper aquifer that recorded a drawdown of approximately $2 \mathrm{~m}$ (Fig. 5). The $2 \mathrm{~m}$ drawdown in the upper aquifer as a consequence of pumping in the lower aquifer could be indicative of enhanced inter-aquifer leakage to the lower aquifer at this location.

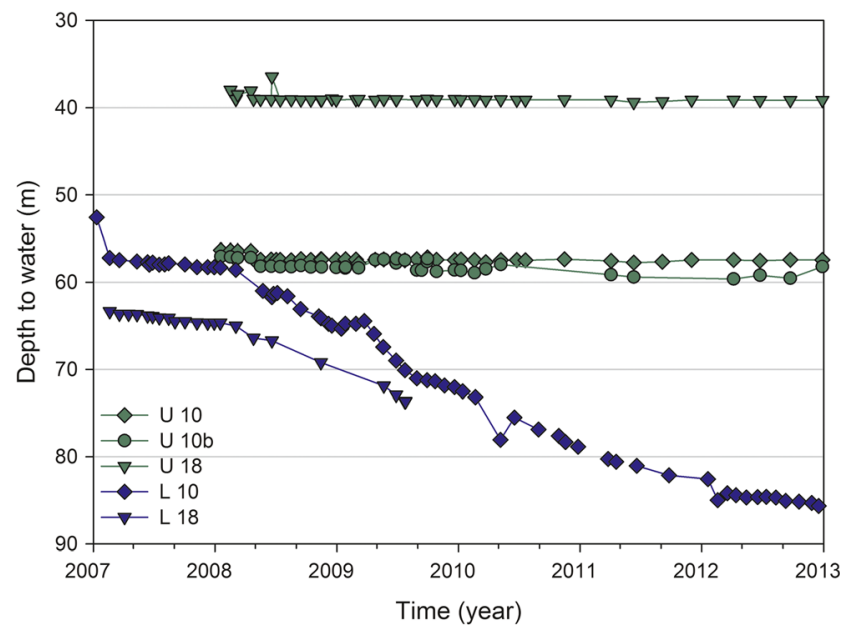

Fig. 5 Depth to water variation over time from pumping wells in the lower aquifer and corresponding upper aquifer wells for well couplets 10 and 18 (Richards 2013). For well locations see Fig. S1 of the ESM

\section{Tracer results}

Hydrochemical results for well couplet groundwater samples, as well as two waterholes and a spring, are presented in Table S2 of the ESM. Chloride concentrations are generally below 7,600 mg/L, except in the lower aquifer at two locations in the western part of the study area, which have concentrations between 21,500-22,800 mg/L (Fig. 6a). At the well couplets, chloride concentrations in the upper aquifer (79$7,600 \mathrm{mg} / \mathrm{L}$ ) are significantly different (t-test gave a $p$-value $<0.1$; Table S2 of the ESM) compared to the lower aquifer (1,800-22,800 mg/L), although some well couplets have similar concentrations (well couplets 4 and 10; Fig. 6a). In addition, the samples from waterholes S3 and S7 and nearby upper aquifer wells $\mathrm{U} 3$ and $\mathrm{U} 7$, respectively, have chloride concentrations $<500 \mathrm{~m} / \mathrm{L}$ (Table $\mathrm{S} 2$ of the ESM).

Most of the data points of the stable isotopes plot along a linear trend (Fig. 7a). The line of best fit from the data in all aquifers $\left(\delta^{2} \mathrm{H}=3.3 \times \delta^{18} \mathrm{O}-22\right)$, excluding the outliers $\mathrm{S} 3$ and U7, intersects the Alice Springs local meteoric water line (LMWL) close to that of the intense rainfall events at $\delta^{2} \mathrm{H}=-46.7$ and $\delta^{18} \mathrm{O}=-7.3$ (Fig. 7a).

$\delta^{13} \mathrm{C}$ values of the upper aquifer $(-3.7$ to $-14.2 \%$ ), as well as the lower aquifer and basement samples $(-7.3$ to $-20.6 \%$ o) have a similar range with no significant difference (Table S2 of the ESM). This limits their application in tracing leakage in this particular study.

The lower aquifer and has a relatively large range in ${ }^{87} \mathrm{Sr} /{ }^{86} \mathrm{Sr}$ ratios $(0.713-0.719)$; and the basement samples fall within this range $(0.714$; Fig. $6 \mathrm{~b})$. The ${ }^{87} \mathrm{Sr} /{ }^{86} \mathrm{Sr}$ ratios are $<0.715$ in the lower aquifer samples L2, L4, L8, L9 and L10, as well as basement samples B7 and B9 (Fig. 6b). There is a tendency for less radiogenic ${ }^{87} \mathrm{Sr} /{ }^{86} \mathrm{Sr}$ ratios in the upper aquifer samples $(0.712-0.714)$, but with no significant difference from the lower aquifer (Table S2 of the ESM). The 

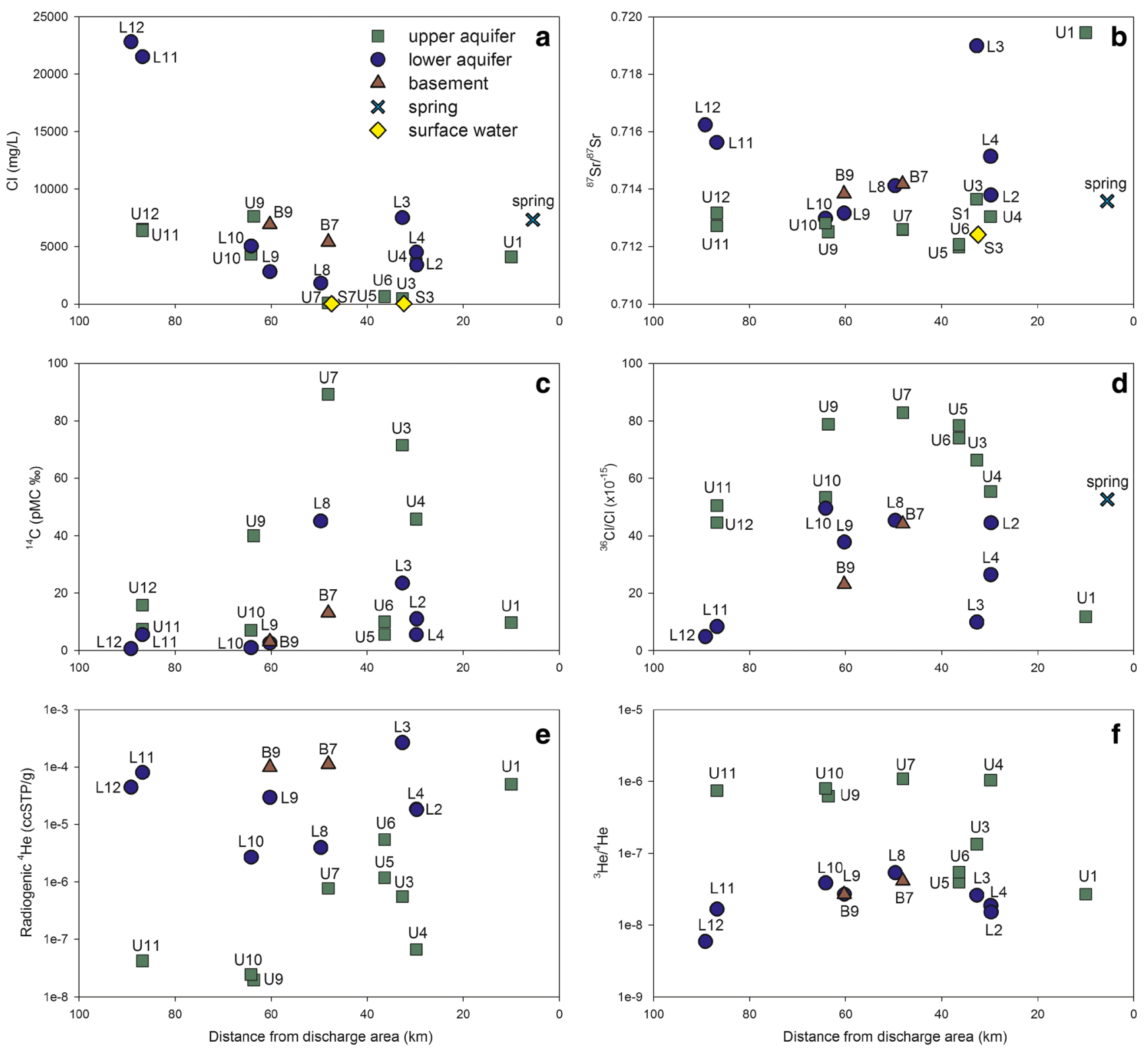

Fig. 6 Environmental tracers plotted against distance from the discharge area: a chloride concentration; $\mathbf{b}{ }^{87} \mathrm{Sr} /{ }^{86} \mathrm{Sr}$ ratio; $\mathbf{c}^{14} \mathrm{C} ; \mathbf{d}{ }^{36} \mathrm{Cl} / \mathrm{Cl} \times 10^{-15} ; \mathbf{e}$ radiogenic ${ }^{4} \mathrm{He}$ concentration; $\mathbf{f}^{3} \mathrm{He} /{ }^{4} \mathrm{He}$ ratio

waterhole sample $\mathrm{S} 3{ }^{87} \mathrm{Sr} /{ }^{86} \mathrm{Sr}$ ratio is 0.712 and sample U1 closest to the discharge zone has the highest ${ }^{87} \mathrm{Sr} /{ }^{86} \mathrm{Sr}$ ratio in the dataset (0.719).

Generally the lower aquifer and basement samples have higher radiogenic ${ }^{4} \mathrm{He}$ concentrations $\left(3 \times 10^{-6}-3 \times 10^{-4} \mathrm{ccSTP} / \mathrm{g}\right)$, as well as lower ${ }^{36} \mathrm{Cl} / \mathrm{Cl}$ ratios $\left(5 \times 10^{-15}-50 \times 10^{-15}\right)$ and ${ }^{14} \mathrm{C}$ activities $(0.6-45 \mathrm{pMC})$ that are significantly different ( $p$-value $<0.10$; Table S2 of the ESM) compared to the upper aquifer (Fig. 6c-e). They also have lower ${ }^{3} \mathrm{He} /{ }^{4} \mathrm{He}$ ratios $\left(6 \times 10^{-9}-5\right.$ $\times 10^{-8}$ ) compared to the upper aquifer samples ( $p$-value $<0.05$; Table S2 of the ESM; Fig. 6f). The majority of the lower aquifer and basement samples have ${ }^{14} \mathrm{C}$ ranging between $0.6-11 \mathrm{pMC}$, except for wells L3, B7 and L8, which have ${ }^{14} \mathrm{C}$ activities of 23 pMC, $13 \mathrm{pMC}$ and $45 \mathrm{pMC}$, respectively. The upper aquifer samples show a large variation in ${ }^{14} \mathrm{C}$ activity $(7-89 \mathrm{pMC})$, with the highest values at $\mathrm{U} 3$ and $\mathrm{U} 7(72$ and $89 \mathrm{pMC}$, respectively).

There is a distinction between the ${ }^{36} \mathrm{Cl} / \mathrm{Cl}$ ratios of the basement/lower aquifers and the upper aquifer (Fig. 6d). The majority of the lower aquifer and basement samples have ${ }^{36} \mathrm{Cl} /$ $\mathrm{Cl}$ ratios varying from $8 \times 10^{-15}$ to $50 \times 10^{-15}$ (Fig. $6 \mathrm{~d}$ ). ${ }^{36} \mathrm{Cl} /$ $\mathrm{Cl}$ ratios are generally higher in the upper aquifer $\left(45 \times 10^{-15}\right.$ $83 \times 10^{-15}$ ), except U1 that has ${ }^{36} \mathrm{Cl} / \mathrm{Cl}=12 \times 10^{-15}$. The ${ }^{36} \mathrm{Cl} /$ $\mathrm{Cl}$ ratio from a spring in the groundwater discharge area is $52 \times 10^{-15}$ (Fig. 6d).

There is a clear distinction between the basement/lower aquifers and the upper aquifer for the radiogenic ${ }^{4} \mathrm{He}$ concentrations and ${ }^{3} \mathrm{He} /{ }^{4} \mathrm{He}$ ratios (Fig. 6e,f). The radiogenic ${ }^{4} \mathrm{He}$ concentrations are lower for the upper aquifer samples 

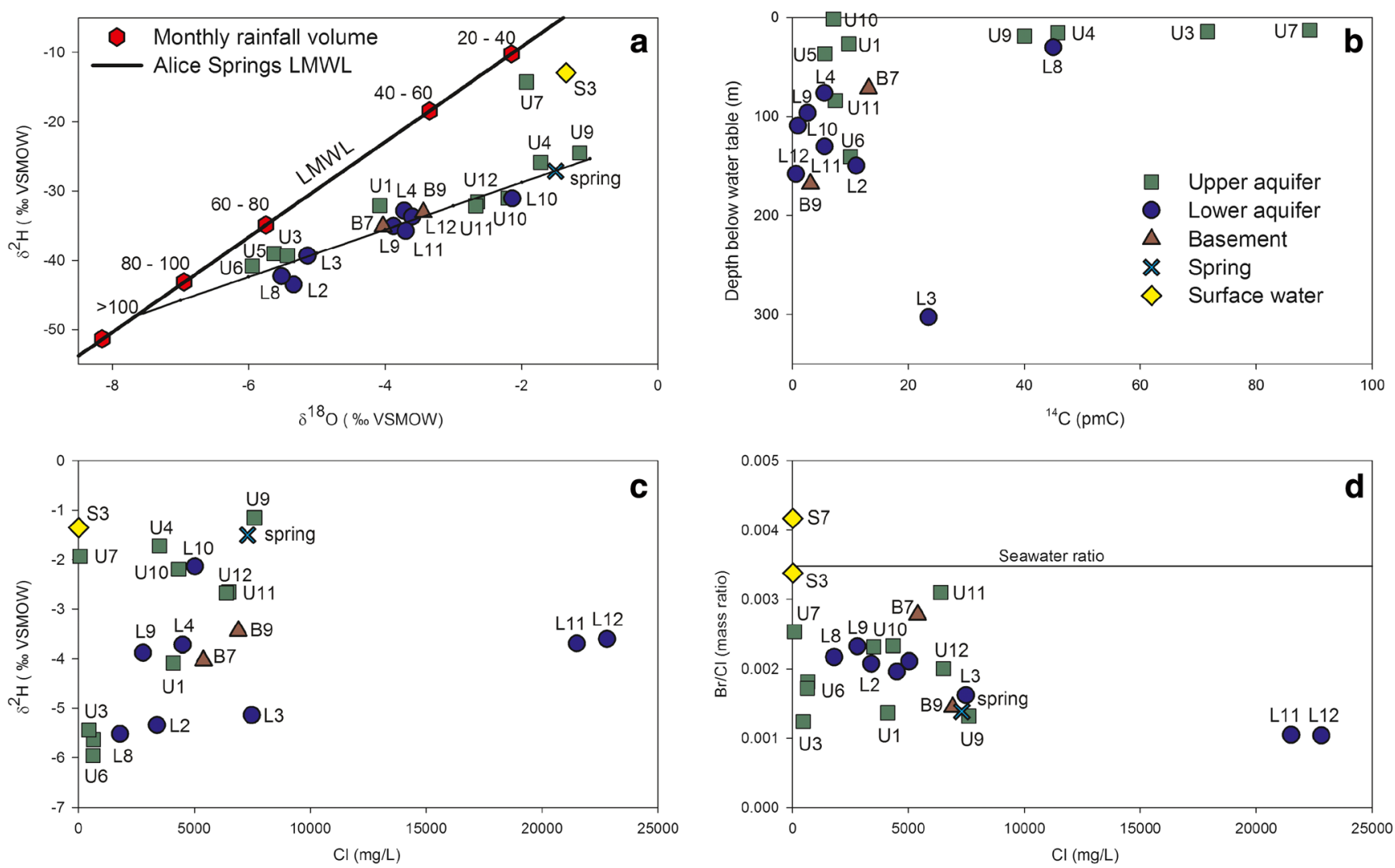

Fig. 7 a $\delta^{2} \mathrm{H}$ plotted against $\delta^{18} \mathrm{O}$ with the local meteoric water line (LMWL) $\delta^{2} \mathrm{H}=7.2 \delta^{18} \mathrm{O}+5.7$ from Alice Springs (Fig. 1b) and amount weighted monthly rainfall volume included (Kretschmer and Wohling

2014). b ${ }^{14} \mathrm{C}$ plotted against sample depth, which is taken as the midpoint of the well screen interval. c $\delta^{2} \mathrm{H}$ plotted against chloride concentration. $\mathbf{d ~} \mathrm{Br} / \mathrm{Cl}$ mass ratio plotted against chloride concentration

$\left(2 \times 10^{-8}-5 \times 10^{-6} \mathrm{ccSTP} / \mathrm{g}\right)$ than in the lower aquifer and basement samples $\left(3 \times 10^{-6}-3 \times 10^{-4} \mathrm{ccSTP} / \mathrm{g}\right)$, except for $\mathrm{U} 1$ $\left(5 \times 10^{-5} \mathrm{ccSTP} / \mathrm{g}\right)$. Samples L10 $\left(3 \times 10^{-6} \mathrm{ccSTP} / \mathrm{g}\right), \mathrm{L} 8$ $\left(4 \times 10^{-6} \mathrm{ccSTP} / \mathrm{g}\right), \mathrm{L} 4\left(2 \times 10^{-5} \mathrm{ccSTP} / \mathrm{g}\right)$ and L2 $\left(2 \times 10^{-5} \mathrm{ccSTP} / \mathrm{g}\right)$ have lower radiogenic ${ }^{4} \mathrm{He}$ concentrations compared to the other lower aquifer wells (Fig. 6e). There appears to be an increase in radiogenic ${ }^{4} \mathrm{He}$ concentrations in some of the upper aquifer wells and, to a smaller extent, the lower aquifer wells with decreasing distance to the discharge area. The ${ }^{3} \mathrm{He} /{ }^{4} \mathrm{He}$ ratios of the lower aquifer and basement samples vary within a band of values between $6 \times 10^{-9}$ to $5 \times 10^{-8}$ (Fig. $6 \mathrm{f}$ ). The ${ }^{3} \mathrm{He} /{ }^{4} \mathrm{He}$ ratios of the upper aquifer samples are commonly higher $\left(9 \times 10^{-7}\right)$, but the ratios of the samples U1, U3, U5 and U6 are markedly lower (Fig. 6f).

\section{Discussion}

\section{Chemical and physical processes}

\section{Regional groundwater flow}

All groundwater samples, except L10 and L12, with ${ }^{14} \mathrm{C}$ above background (> $1 \mathrm{pMC}$ ) likely contain ${ }^{14} \mathrm{C}_{\mathrm{DIC}}$ with a

residence time of $<30 \mathrm{ka}$. In fact, groundwater samples with ${ }^{14} \mathrm{C}>40 \mathrm{pMC}$ (U3, U4, U 7, U 9 and L8) are likely to contain ${ }^{14} \mathrm{C}_{\text {DIC }}$ with a residence time of $<6 \mathrm{ka}$. Groundwater samples of which there has been substantial decay of ${ }^{36} \mathrm{Cl}\left({ }^{36} \mathrm{Cl} /\right.$ $\mathrm{Cl}<45 \times 10^{-15}$; U1, L2, L3, L4, L9, L11, L12, B7 and B9) have residence times of several 10's to 100's ka (Love et al. 2000). Groundwater residence times could be greater than $500 \mathrm{ka}$ in those areas where groundwater samples (U1, L2, L3, L4, L9, L11, B7 and B9) with radiogenic ${ }^{4} \mathrm{He}>1 \times 10^{-5}$ $\operatorname{ccSTP} / \mathrm{g}$, assuming $1 \times 10^{-12}-10 \times 10^{-12} \mathrm{ccSTP} / \mathrm{g} / \mathrm{yr}$ radiogenic ${ }^{4} \mathrm{He}$ input (Torgersen and Clarke 1985; Bethke et al. 1999; Gardner et al. 2012).

Measureable ${ }^{14} \mathrm{C}$ points to a maximum residence time of $30 \mathrm{ka}$. For a residence time of $30 \mathrm{ka}$ the ${ }^{36} \mathrm{Cl}$ would have decayed by no more than $7 \%$ (based on $\mathrm{C}=\mathrm{C}_{\mathrm{o}} \mathrm{e}^{-\lambda \mathrm{t}}$, with $t$ $=30,000$ years), and radiogenic ${ }^{4} \mathrm{He}$ should not exceed $3 \times$ $10^{-8}-30 \times 10^{-8} \mathrm{ccSTP} / \mathrm{g} / \mathrm{yr}$ (assuming $1 \times 10^{-12}-10 \times 10^{-12}$ $\operatorname{ccSTP} / \mathrm{g} / \mathrm{yr}$ input for $30 \mathrm{ka}$ ). However, throughout this study area the age tracers were beyond these theoretical limits emphasising the importance of mixing of different 'age' groundwater, and possibly the influx of tracers by diffusion (Walker and Cook 1991). Because of the low groundwater flow velocities, diffusion of age and other tracers could be more relevant here than in areas with higher flow rates-for 
example, ${ }^{14} \mathrm{C}$ could diffuse in from above and radiogenic ${ }^{4} \mathrm{He}$ could diffuse from below.

The ${ }^{14} \mathrm{C}$ value of $23 \mathrm{pMC}$ at $\mathrm{L} 3$ is inconsistent with the hydraulic data and the other age tracers $\left({ }^{36} \mathrm{Cl} / \mathrm{Cl} \mathrm{ra}\right.$ tio $<45 \times 10^{-15}$ and radiogenic ${ }^{4} \mathrm{He}>1 \times 10^{-5} \mathrm{ccSTP} / \mathrm{g}$ ), as well as the depth of the well ( $300 \mathrm{~m}$; Fig. $7 \mathrm{~b})$. The reason for this inconsistency is unknown, but it is unlikely to be representative for the groundwater in the lower aquifer at that location.

The upper aquifer samples in the westernmost part of the study area (U10, U11 and U12) with radiogenic ${ }^{4} \mathrm{He}<1 \times 10^{-7} \mathrm{ccSTP} / \mathrm{g}$ and ${ }^{36} \mathrm{Cl} / \mathrm{Cl}$ values $>45 \times 10^{-15}$, have groundwater residence times less than several 10's ka. Groundwater samples further to the east (U5, U6 and U1) have low ${ }^{14} \mathrm{C}$ values ${ }^{14} \mathrm{C}(<10 \mathrm{pMC})$ and higher radiogenic ${ }^{4} \mathrm{He}$ concentrations $\left(>1 \times 10^{-6} \mathrm{ccSTP} / \mathrm{g}\right)$, indicating groundwater residence times of several 100's ka. The inconsistency between ${ }^{14} \mathrm{C}$, radiogenic ${ }^{4} \mathrm{He}$ and ${ }^{36} \mathrm{Cl} / \mathrm{Cl}$ is possibly due to mixing and diffusion; however, the general pattern of increasing groundwater residence times is consistent with the westeast directed groundwater flow in the upper aquifer, as inferred from the hydraulic head distribution (Fig. 1a). The lower aquifer and basement groundwater residence times are generally older (several 10's to 100 's ka) than the upper aquifer, with the highest radiogenic ${ }^{4} \mathrm{He}$ concentrations $\left(2 \times 10^{-4}\right.$ $\operatorname{ccSTP} / g$ ), and, hence oldest groundwater, toward the end of the inferred groundwater flow path at L3 (Fig. 1a).

\section{Recharge}

Love et al. (2013) contended that recharge to the upper aquifer would occur at ephemeral rivers where the aquifer sub-crops or the upper aquitard is absent. Groundwater samples in the upper aquifer close to ephemeral rivers (samples U3, U4 and U9) and waterholes (samples also U3 and U7) with ${ }^{14} \mathrm{C}_{\text {DIC }}$ residence times of $<6 \mathrm{ka}$ support this interpretation. Additionally, the chloride concentrations in the upper aquifer samples U3 and U7 $(<500 \mathrm{mg} / \mathrm{L})$ are significantly lower than the surrounding upper aquifer $(\sim 3,500 \mathrm{mg} / \mathrm{L})$, and comparable to the surface-water samples $(<100 \mathrm{mg} / \mathrm{L}$; Fig. 6a). However, radiogenic ${ }^{4} \mathrm{He}$ groundwater residence time estimates greater than several 10 's ka at some of these locations (U3 and U7; Fig. 6e) indicate that modern water mixes with older water; therefore, where ephemeral surface water features exist, even where the upper aquitard is present (Fig. S1a of the ESM), the distribution of age tracers represent pulses of younger water punctuating the increasing age of groundwater along the flow paths. Whilst this was apparent for samples U3, U4, U7 and U9 $\left({ }^{14} \mathrm{C}_{\text {DIC }}\right.$ residence times of $\left.<6 \mathrm{ka}\right)$ near surface water features, the spatial resolution of the dataset was insufficient to identify areas of recharge more precisely.

Groundwater samples further to the east and away from the ephemeral rivers (U1, U5, U6 and U10; Fig. 3) have low ${ }^{14} \mathrm{C}$ values $(<10 \mathrm{pMC})$ indicating little to no addition of modern water at these locations. Therefore, there is no evidence for preferential recharge in those upper aquifer samples located away from ephemeral rivers.

The stable water isotope data (Fig. 7a) plot along a straight line with a low slope of 3.3 that is indicative of waters that have undergone evaporation as well as mixing. Considering that groundwater residence time can be $>500 \mathrm{ka}$, some of the groundwater would have been recharged during wetter climatic periods, consistent with previous work in the adjacent GAB (Love et al. 2013). Nevertheless, extrapolating the line to the LMWL suggests that recharge is predominantly from intense rainfall events with volumes between 80 and $100 \mathrm{~mm} / \mathrm{month}$ (Keppel et al. 2015) being consistent with other areas in Central Australia (Harrington et al. 2002). S3 (a water hole sample) and U7, sitting off this common trend line, are most likely explained by recent evaporated rainfall derived from smaller volume rainfall events.

\section{Chemical processes}

The data point of the stable water isotopes delta values plotted against chloride (Fig. 7c) do not show a straight-line relationship highlighting that processes other than simple evapotranspiration have been important. Groundwater mixing affects these tracers as well as recharge from evaporated surfacewater features. Preferential recharge from surface-water features along the groundwater flow path allows mixing of modern, fresh groundwater with older, saltier groundwater leading to groundwater in the centre of the study area with the decreased residence times and chloride concentrations. The origin of the high salinity is most likely fallout of marine and continentally derived salts from the atmosphere and a subsequent evaporative enrichment as it has been described for other sedimentary basins of Australia (Herczeg et al. 2001) as well as dissolution of halite. Complete evaporation of all rainwater during some years, and the precipitation of the salts contained in it, followed by recharge, and re-dissolution of salts during wetter years could contribute to the halite signature. Chloride/bromide mass ratios consistently below the seawater dilution line (Fig. 7d) are evidence of halite dissolution, in addition to evaporation and mixing, control on chloride concentrations.

Upper and lower aquifers $\delta^{13} \mathrm{C}$ ratios have a similar range representing similar origin $\delta^{13} \mathrm{C}$; with $\delta^{13} \mathrm{C}$ soil input and carbonate dissolution with no significant difference between the aquifers (Table $\mathrm{S} 2$ of the ESM). Because the $\delta^{13} \mathrm{C}$ values between the aquifers are similar, it is not possible to distinguish mixing or enhanced inter-aquifer leakage using this tracer-

The upper aquifer ${ }^{87} \mathrm{Sr} /{ }^{86} \mathrm{Sr}$ ratios $(0.712-0.714$, excluding $\mathrm{U1}$ ) only show a small variation from the recharging groundwater ( $\mathrm{S} 3$ with ${ }^{87} \mathrm{Sr} /{ }^{86} \mathrm{Sr}=0.712$ ), so weathering exchange in 
the upper aquifer may occur between atmospheric $\mathrm{Sr}$ (ca. 0.709 ) and aquifer minerals with an ${ }^{87} \mathrm{Sr} /{ }^{86} \mathrm{Sr}$ ratio of approximately 0.714 . The lower aquifer and basement groundwater samples show slightly higher variability with ${ }^{87} \mathrm{Sr} /{ }^{86} \mathrm{Sr}$ up to 0.719 . Therefore, there may be more radiogenic ${ }^{87} \mathrm{Sr}$ in the minerals undergoing weathering in the lower aquifers. Mixing and enhanced inter-aquifer leakage from the upper aquifer may cause the large variability in ${ }^{87} \mathrm{Sr} /{ }^{86} \mathrm{Sr}$ ratios in the lower aquifer and basement samples, and this is examined further in section 'Enhanced inter-aquifer leakage'. However, it cannot be ruled out that weathering-derived ${ }^{87} \mathrm{Sr} /{ }^{86} \mathrm{Sr}$ may not be uniform across the aquifers.

\section{Stagnant zones}

The high salinity of the groundwater in the lower aquifer (L11 and $\mathrm{L} 12$, with 21,500 and $22,800 \mathrm{mg} / \mathrm{L} \mathrm{Cl}$, respectively; Fig. 6a) is seemingly at odds with its position in the upstream part of the lower aquifer flow field. While $\mathrm{L} 11$ has ${ }^{14} \mathrm{C}$ above background $\left(5.5 \mathrm{pMC} ;{ }^{14} \mathrm{C}_{\mathrm{DIC}}\right.$ with a residence time of $<30 \mathrm{ka}$ ), both L11 and L12 show substantial decay of ${ }^{36} \mathrm{Cl}$, and high radiogenic ${ }^{4} \mathrm{He}$ concentrations indicating groundwater residence times up to several 100's ka (Fig. 6c-e). In these two locations, there could be mixing of old and a small amount of young water, or diffusion of ${ }^{14} \mathrm{C}$, in the stagnant zones. Indeed the lower aquifer seems not to form a continuous unit everywhere in the Arckaringa Basin as regions of low-permeability are known to occur (Howe et al. 2008; SKM 2009). Suckow et al. (2016) reported similar findings for the Surat Basin. The origin of the high salinity is most likely evaporative enrichment of atmospherically derived salts, as has been found for groundwater in sedimentary basins elsewhere in Australia (Herczeg et al. 2001). The relatively high salt concentration must indicate that the evaporative solute enrichment process acted with greater intensity on groundwater in this part of the aquifer than in other parts, which may be linked to much dryer climatic conditions in the past. This would mean that these saline groundwaters are no longer formed under the current hydrological conditions, and have been replaced by fresher groundwater in areas where there is active flow.

\section{Inter-aquifer leakage}

\section{Diffuse inter-aquifer leakage}

Density corrected freshwater heads at the well couplets show that downward leakage is possible throughout the majority of the study area. Where the lower aquitard is present, diffuse leakage is estimated to be $q_{v}<1 \mathrm{~mm} / \mathrm{yr}$. Density corrected freshwater heads at well couplets located near the northeastern spring discharge area (well couplets 1 and 3 ) indicate upward groundwater flow. Indeed, the age tracer values and
${ }^{87} \mathrm{Sr} /{ }^{86} \mathrm{Sr}$ ratio of sample $\mathrm{U} 1$ are similar to the distribution in the lower but not to the upper aquifer-e.g. most radiogenic ${ }^{87} \mathrm{Sr} /{ }^{86} \mathrm{Sr}$ ratio, residence time of several 10's to 100's ka (high radiogenic ${ }^{4} \mathrm{He}$ concentration low ${ }^{36} \mathrm{Cl} / \mathrm{Cl}$ ratio and low ${ }^{14} \mathrm{C}$ value) and ${ }^{3} \mathrm{He} /{ }^{4} \mathrm{He}$ ratio $<1 \times 10^{-7}$ (Fig. 6b-f). The interpretation of sample $\mathrm{U} 3$ is less straightforward because it has high ${ }^{14} \mathrm{C}$ values with ${ }^{14} \mathrm{C}_{\mathrm{DIC}}$ with a residence time of $<30 \mathrm{ka}$ in combination with a high ${ }^{4} \mathrm{He}$ concentration with a residence time of $>500 \mathrm{ka}$, and ${ }^{3} \mathrm{He} /{ }^{4} \mathrm{He}$ ratio $<1 \times 10^{-7}$. Samples consisting of waters of different age are known to yield conflicting age tracer values (Bethke and Johnson 2008; Suckow 2013).

\section{Enhanced inter-aquifer leakage}

Where the lower aquitard is absent, the hydraulic resistance is reduced and leakage between the aquifers increases up to $q_{v}=$ $7 \mathrm{~m} / \mathrm{yr}$ (Fig. 3). The increased rate is consistent with the age tracer values suggesting mixing or addition of younger water in the lower aquifer where the aquitard is absent. This mixing is evident from lower radiogenic ${ }^{4} \mathrm{He}$ concentrations (L8, L4 and L2), as well as higher ${ }^{14} \mathrm{C}$ values ( $\left.\mathrm{L} 8\right)$ and ${ }^{36} \mathrm{Cl} / \mathrm{Cl}$ ratios (L 8 and $\mathrm{L} 2$ ) if compared to surrounding groundwater samples from the lower aquifer and basement (Fig. 6c-e).

The areas where the lower aquitard is thin $(<25 \mathrm{~m})$ and with a higher incidence of tectonic features have been interpreted as areas where enhanced inter-aquifer leakage is most likely (Fig. 3). It was hypothesised that zones of enhanced downward inter-aquifer leakage would be apparent from anomalies in age tracer values in the lower aquifer, and overlap in environmental tracer concentrations, or isotope ratios, between the upper aquifer and the lower aquitard. This seems to be the case at well couplet 10, and possibly at well couplets 7 and 9, because the age tracers indicate the addition of younger water to the lower aquifer and basement at L10 and L9 (indicated by ${ }^{36} \mathrm{Cl} / \mathrm{Cl}$ and ${ }^{4} \mathrm{He}$ ) and $\mathrm{B} 7$ (indicated by ${ }^{36} \mathrm{Cl} /$ $\mathrm{Cl}$ and $\left.{ }^{14} \mathrm{C}\right)$. The ${ }^{87} \mathrm{Sr} /{ }^{86} \mathrm{Sr}$ ratios are less radiogenic and more similar to the upper aquifer (L9, L10, B7 and B9), and furthermore, there is overlap in chloride concentration, $\delta^{2} \mathrm{H}$ and $\delta^{18} \mathrm{O}$ in the upper and lower aquifers at well couplet 10 . At well couplets 7 and 9, the freshwater head difference is similar to most of the other couplets, but at site 10 , the difference is less than $5 \mathrm{~m}$. Moreover, a hydraulic connection between the aquifers at well couplet 10 may be indicated by a slight drawdown at U10b, which was recorded during the pumping of groundwater from the lower aquifer (Fig. 5). This could also explain why the pre-pumping head difference was small at this location. The reason for the inferred hydraulic connection at couplet 10 is unclear. Well couplet 10 is less than $3 \mathrm{~km}$ from an interpreted fault zone but without more detailed data on the structural geology the hydrogeological role of faults cannot be ascertained. Well couplets 7 and 9 are also similar distances from interpreted fault zones, but at these locations, the 
thinning and pinching out of the aquitard may also cause greater aquifer connectivity, because these couplets are located within $5 \mathrm{~km}$ from the inferred extent of the aquitard. Figure 3 summarises the locations of enhanced inter-aquifer leakage through the lower aquitard and downward leakage being identified by hydraulics and tracers.

Previous studies have used end-member-mixing massbalance models using ${ }^{87} \mathrm{Sr} /{ }^{86} \mathrm{Sr}$ ratios to estimate the proportion of inter-aquifer mixing (Dogramaci and Herczeg 2002; Shand et al. 2009). Attempts to use this model to quantify the mixing ratio between upper and lower aquifer groundwater for sample L10, the site with the strongest indications for interaquifer leakage, are hampered by the difficulty of selecting appropriate ${ }^{87} \mathrm{Sr} /{ }^{86} \mathrm{Sr}$ ratio weathering end members. Clearer distinction between radiogenic ${ }^{4} \mathrm{He}$ concentrations in the upper and lower aquifer and less spatial variation within each aquifer make selecting radiogenic ${ }^{4} \mathrm{He}$ end members relatively easier, which is also due to order of magnitude differences in the radiogenic ${ }^{4} \mathrm{He}$ concentrations compared to the Sr isotopes. As such, either L12 or B9 could be representative of the lower aquifer and U10 for the upper aquifer. Following the mixing calculations in Faure (1986) using both ${ }^{87} \mathrm{Sr} /{ }^{86} \mathrm{Sr}$ ratios and radiogenic ${ }^{4} \mathrm{He}$ concentrations up to $80-95 \%$ of groundwater in L10 could originate from the upper aquifer (Fig. 8a,b).

\section{Evaluation of method}

This study evaluated a comprehensive approach to investigate inter-aquifer leakage on a regional scale where only limited wells are available. However, it is noted that the collection and analyses of multiple environmental tracers is costly and may prohibit the use of this method elsewhere. The usefulness of each of the investigation methods, or combinations thereof, is therefore summarised in Table 1 and discussed in the following.

The availability of well couplets was an essential prerequisite for the successful detection of inter-aquifer leakage. Based on the hydraulics and multiple environmental tracers enhanced inter-aquifer leakage could be identified at these sites. The similarities between environmental tracer concentrations, or isotope ratios, in the upper and lower aquifer show that enhanced inter-aquifer leakage may be occurring where freshwater hydraulic heads are similar in both aquifers, such as exemplified by well couplet 10. Small head differences may thus be indicators of the presence of windows of enhanced permeability within the aquitard. Pumping from the lower aquifer and a respective drawdown in the upper aquifer supported the assertion of enhanced inter-aquifer leakage at well couplet 10. It requires, however, that no or minimal aquifer abstraction is occurring in one of the aquifers of interest
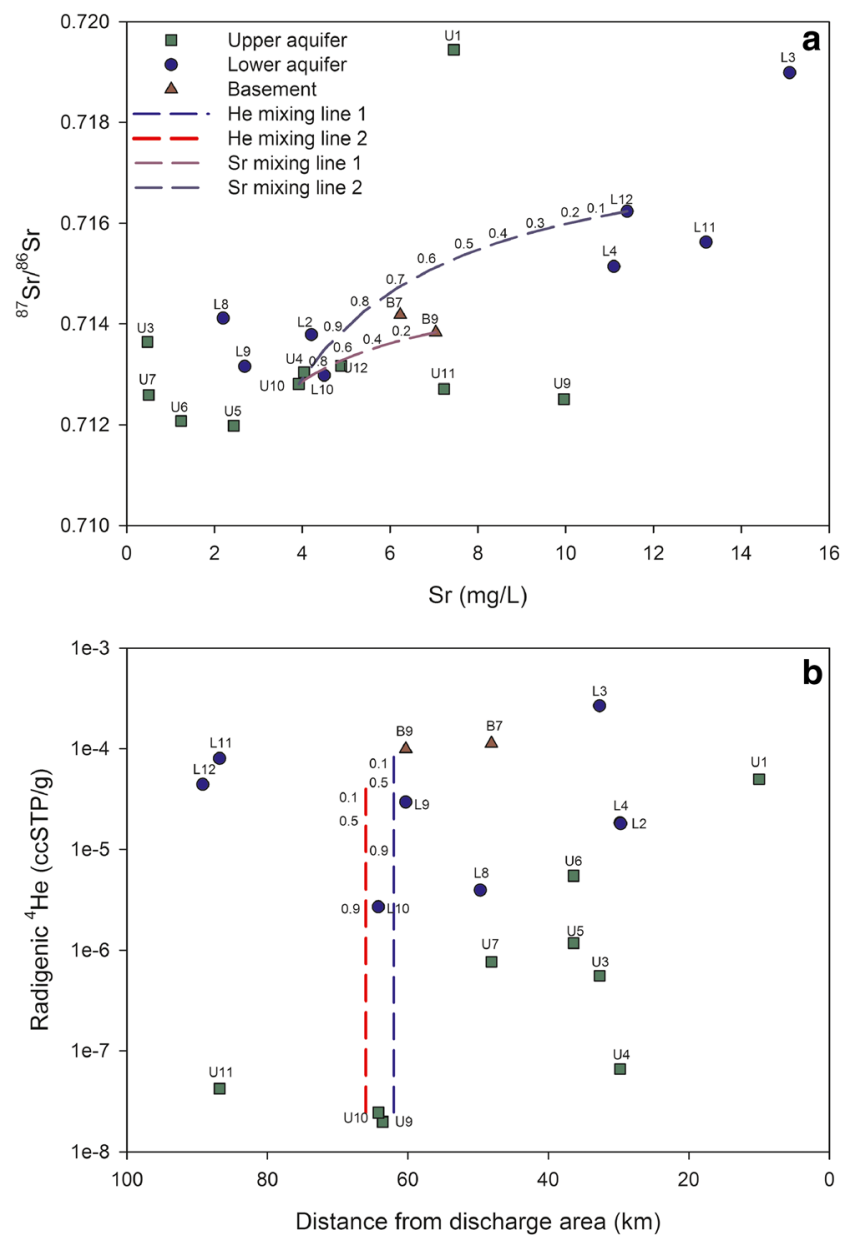

Fig. 8 a ${ }^{87} \mathrm{Sr} /{ }^{86} \mathrm{Sr}$ ratio plotted against $\mathrm{Sr}$ concentration. The two theoretical end-member mixing lines for well couplet 10 are shown with U10 representing the upper aquifer end member and L12 (dark blue dashed line) or B9 (purple dashed line) representing the lower aquifer end member. Mixing lines labelled with fraction of upper aquifer sample. b Radiogenic ${ }^{4} \mathrm{He}$ concentration plotted against distance from the discharge area. Given that L12 (red dashed line) or B9 (blue dashed line) may be representative of the lower aquifer and U10 represents the upper aquifer, the two theoretical end-member mixing lines have been calculated for well couplet 10 . The two mixing lines have been arbitrarily placed on the $\mathrm{x}$-axis alongside well couplet 10. Mixing lines labelled with fraction of upper aquifer sample

(Neuman and Witherspoon 1972), which is not always the case.

Regional overviews of the hydraulic resistance of the lower aquitard and locations of interpreted faults were not useful to identify locations of enhanced inter-aquifer leakage; however, the hydraulic resistance and vertical Darcy flux provides an indication of diffuse leakage direction and flow rate through the aquitard pore spaces which can be extremely useful for regional-scale water balance models.

Some studies have been able to quantify mixing with other environmental tracers, such as $\mathrm{Cl}, \delta{ }^{13} \mathrm{C}$ and the stable isotopes of water (Dogramaci and Herczeg 


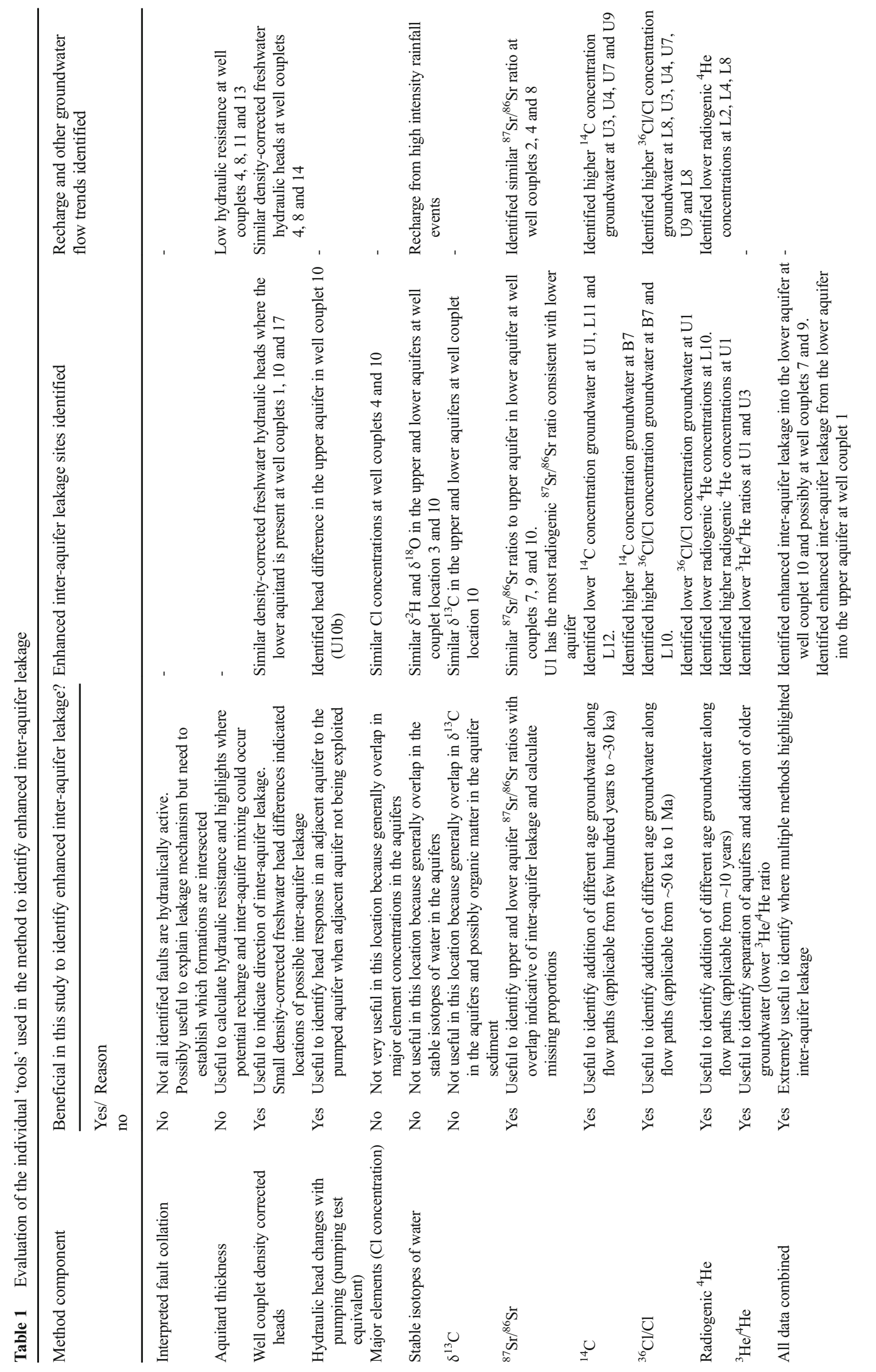


2002; Trabelsi et al. 2009; Wang et al. 2013); however, this was not possible in this study area as there was a range of values and no significant differentiation between the aquifers for those tracers. Radiogenic ${ }^{4} \mathrm{He}$ concentrations and ${ }^{87} \mathrm{Sr} /{ }^{86} \mathrm{Sr}$ ratios made it possible to quantify the proportion of enhanced inter-aquifer leakage at one site, but the difficulty in the identification of a suitable end member restricted the broad use of $\mathrm{Sr}$.

In contrast, the clearest evidence came from the tracers that are transient in time. The use of three age tracers was found to be helpful for the purpose of this study. The different age tracers are applicable over different timescales, which allows identification of enhanced inter-aquifer leakage of groundwater of different residence times - for example, addition of older groundwater to the upper aquifer at well location 1 was evidenced by a large variation in ${ }^{14} \mathrm{C}$ and ${ }^{36} \mathrm{Cl} / \mathrm{Cl}$ but less obvious with regards to the respective radiogenic ${ }^{4} \mathrm{He}$ concentration. Alternatively, addition of younger groundwater to the lower aquifer at L2, L4, L8 and L10 was most obvious in the radiogenic ${ }^{4} \mathrm{He}$ concentration. Radiogenic ${ }^{4} \mathrm{He}$ is the most sensitive to these changes as it varied over 5 orders of magnitude, compared to just 2 orders of magnitude for ${ }^{14} \mathrm{C}$ and ${ }^{36} \mathrm{Cl} / \mathrm{Cl}$. The use of transient tracers is especially important in large groundwater basins with groundwater residence times that can vary considerably. ${ }^{14} \mathrm{C}$ and ${ }^{36} \mathrm{Cl} / \mathrm{Cl}$ values were found useful to identify localised surface-water recharge locations. The range of residence time tracers can give inconsistent results as in this study, but this provides a powerful tool to evaluate mixing of groundwater e.g. the presence of ${ }^{14} \mathrm{C}$ in very old waters suggest a younger component to be present in the groundwater. Similar findings have been reported for other basins (Suckow et al. 2016), as well as theoretically (McCallum et al. 2017). Additionally, because of the low groundwater flow rates the vertical diffusion of age and other tracers may be more pertinent compared to areas with higher flow rates.

The protocol of well couplet hydrochemistry sampling and analysis methodologies proposed could be applied elsewhere to investigate inter-aquifer leakage at a regional scale. A multi-tracer approach along with groundwater hydraulics provides a tool-set to investigate enhanced inter-aquifer leakage in a regional-scale sedimentary basin with a paucity of data. While the usefulness of individual environmental tracers as tools to identify enhanced inter-aquifer leakage is dependent on climatic, geological, hydrogeological and hydrochemical conditions, and just as in this study, it is possible that only some of the tracers would be useful, the authors strongly recommend the use of multiple environmental tracers, and especially multiple age tracers.

\section{Conclusions}

Inter-aquifer leakage between the GAB and Arckaringa Basin was analysed with sparse observation points using geological, hydrological and tracer information. An upper (GAB) and lower aquifer (Arckaringa Basin) are separated by an aquitard that can reach a thickness of up to $300 \mathrm{~m}$, but pinching out toward the western and eastern parts of the study area. The diffuse inter-aquifer leakage rates are estimated to be $<1 \mathrm{~mm} /$ $\mathrm{yr}$ where the lower aquitard is thick and continuous. Interaquifer leakage rates are higher where the lower aquitard is absent, such as in the south-eastern part of the study area.

Recharge into the upper aquifer (GAB) from ephemeral streams and waterholes is recognised at several locations. Stable water isotope values indicate that recharge is derived mainly from high-intensity rainfall events. There is evidence for downward enhanced inter-aquifer leakage, in one region, where the lower aquitard is continuous; moreover, there may be downward enhanced inter-aquifer leakage near the margin of the aquitard as well as upward enhanced inter-aquifer leakage in the spring discharge area. This spatial distribution could be the result of thinning of the aquitard or focused leakage surrounding fault zones. There is no evidence for enhanced inter-aquifer leakage in other areas of the groundwater system where the aquitard is present. Considering there is evidence that preferential flow exists at some locations, it is possible that enhanced inter-aquifer leakage could occur at other locations across the basin, but the monitoring infrastructure lacks the resolution to establish this with certainty. Nevertheless it is an important outcome, especially from a management point of view. Any future development should be accompanied by a local-scale assessment of the nature of the leakage, supported by commensurate data such as seismics to verify the continuity of layers.

A scarcity of wells can be a major obstacle when investigating inter-aquifer leakage locations and even the most comprehensive set of tracers cannot solve that problem. However, this study provides baseline information at a regional scale that can be used prior to increased groundwater abstraction for mining or other activities in the groundwater basin.

Acknowledgements This study and paper were funded by the Government of South Australia's Department of Environment, Water and Natural Resources (DEWNR), Australia under its Bioregional Assessment Program on the Arckaringa Basin. The authors would also like to thank AINSE Ltd for providing financial assistance (Award PGRA) to Stacey Priestley. We thank Peter Kretschmer for assistance in the field. Noble gases analysis was completed at the noble gas laboratory of the Swiss Federal Institute of Technology (ETH) and we thank Matthias Brennwald for help with analysis. We thank the traditional owners and custodians (past and present) of the South Australian spring country, particularly the Antakarinja peoples. We also thank the pastoralist and graziers of the south-western GAB, in particular Millers Creek Station, Billa Kalina Station and Anna Creek Station. Finally, we thank OZ Minerals and BHP Billiton for access to their mine water supply wells. 
Open Access This article is distributed under the terms of the Creative Commons Attribution 4.0 International License (http:// creativecommons.org/licenses/by/4.0/), which permits unrestricted use, distribution, and reproduction in any medium, provided you give appropriate credit to the original author(s) and the source, provide a link to the Creative Commons license, and indicate if changes were made.

\section{References}

Allan RJ (1990) Climate. In: Tyler MJ, Twidale CR, Davies M et al (eds) Natural history of the north east deserts. Royal Soc. of South Australia, Adelaide, Australia, pp 107-118

Alley WM, Healy RW, LaBaugh JW, Reilly TE (2002) Hydrology: flow and storage in groundwater systems. Science 296(5575):19851990. doi:10.1126/science. 1067123

Ambrose GJ, Flint RB (1980) Billa Kalina, South Australia. Explanatory Notes. 1:250,000 geological series, Geological sheet SH 53-7. Geological Survey of South Australia, Adelaide, Australia

Arslan S, Yazicigil H, Stute M, Schlosser P, Smethie WM Jr (2015) Analysis of groundwater dynamics in the complex aquifer system of Kazan Trona, Turkey, using environmental tracers and noble gases. Hydrogeol J 23(1):175-194. doi:10.1007/s10040-014-1188-Z

Bachu S (1995) Flow of variable-density formation water in deep sloping aquifers: review of methods of representation with case studies. J Hydrol 164(1-4):19-38. doi:10.1016/0022-1694(94)02578-Y

Batlle-Aguilar J, Cook PG, Harrington GA (2016) Comparison of hydraulic and chemical methods for determining hydraulic conductivity and leakage rates in argillaceous aquitards. J Hydrol 532:102121. doi:10.1016/j.jhydrol.2015.11.035

Bethke CM, Johnson TM (2008) Groundwater age and groundwater age dating. Ann Rev Earth Planet Sci 36:121-152. doi:10.1146/annurev. earth.36.031207.124210

Bethke CM, Zhao X, Torgersen T (1999) Groundwater flow and the ${ }^{4} \mathrm{He}$ distribution in the Great Artesian Basin of Australia. J Geophys Res Solid Earth 104(B6):12999-13011. doi:10.1029/1999JB900085

Brantley SL, Yoxtheimer D, Arjmand S, Grieve P, Vidic R, Pollak J, Llewellyn GT, Abad J, Simon C (2014) Water resource impacts during unconventional shale gas development: the Pennsylvania experience. Int J Coal Geol 126:140-156. doi:10.1016/j.coal.2013.12. 017

Bredehoeft JD, Neuzil CE, Milly PC (1983) Regional flow in the Dakota aquifer: a study of the role of confining layers. US Geol Surv Water Suppl Pap 2237

Brenot A, Négrel P, Petelet-Giraud E, Millot R, Malcuit E (2015) Insights from the salinity origins and interconnections of aquifers in a regional scale sedimentary aquifer system (Adour-Garonne district, SW France): contributions of $\delta^{34} \mathrm{~S}$ and $\delta^{18} \mathrm{O}$ from dissolved sulfates and the ${ }^{87} \mathrm{Sr} /{ }^{86} \mathrm{Sr}$ ratio. Appl Geochem 53:27-41. doi:10.1016/j. apgeochem.2014.12.002

Candela L, Elorza FJ, Tamoh K, Jiménez-Martínez J, Aureli A (2014) Groundwater modelling with limited data sets: the Chari-Logone area (Lake Chad Basin, Chad). Hydrol Process 28(11):3714-3727. doi:10.1002/hyp.9901

Cartwright I, Weaver TR, Cendón DI, Fifield LK, Tweed SO, Petrides B, Swane I (2012) Constraining groundwater flow, residence times, inter-aquifer mixing, and aquifer properties using environmental isotopes in the southeast Murray Basin, Australia. Appl Geochem 27(9):1698-1709. doi:10.1016/j.apgeochem.2012.02.006

Cherry JA, Parker BL (2004) Role of aquitards in the protection of aquifers from contamination: a "state of science" report. AWWA Research Foundation, Denver, $\mathrm{CO}$

Clark JF, Stute M, Schlosser P, Drenkard S (1997) A tracer study of the Floridan aquifer in southeastern Georgia: implications for groundwater flow and paleoclimate. Water Resour Res 33(2):281289. doi:10.1029/96wr03017

Cowley VM, Martin AR (1991) Kingoonya, South Australia. Explanatory notes. 1:250,000 geological series. Geological sheet SH 53-11. Geological Survey of South Australia, Adelaide, Australia

Cudennec C, Leduc C, Koutsoyiannis D (2007) Dryland hydrology in Mediterranean regions: a review. Hydrol Sci J 52(6):1077-1087. doi:10.1623/hysj.52.6.1077

Dogramaci SS, Herczeg AL (2002) Strontium and carbon isotope constraints on carbonate-solution interactions and inter-aquifer mixing in groundwaters of the semi-arid Murray Basin. Australia J Hydrol 262(1-4):50-67. doi:10.1016/S0022-1694(02)00021-5

Dogramaci SS, Herczeg AL, Schiff SL, Bone Y (2001) Controls on $\delta^{34}$ S and $\delta^{18} \mathrm{O}$ of dissolved sulfate in aquifers of the Murray Basin, Australia and their use as indicators of flow processes. Appl Geochem 16(4):475-488. doi:10.1016/S0883-2927(00)00052-4

Drexel JF, Preiss WV (1995) The geology of South Australia, vol 2: the Phanerozoic. Bulletin 54, South Australia Geological Survey, Adelaide, Australia

Faure G (1986) Principles of isotope geology. Wiley, New York

Field RA, Soltis J, Murphy S (2014) Air quality concerns of unconventional oil and natural gas production. Environ Sci: Processes Impacts 16(5):954-969. doi:10.1039/c4em00081a

Freeze RA, Witherspoon PA (1967) Theoretical analysis of regional groundwater flow: 2. effect of water-table configuration and subsurface permeability variation. Water Resour Res 3(2):623-634. doi: 10.1029/WR003i002p00623

Gardner WP, Harrington GA, Smerdon BD (2012) Using excess ${ }^{4} \mathrm{He}$ to quantify variability in aquitard leakage. J Hydrol 468:63-75. doi:10. 1016/j.jhydro1.2012.08.014

Glynn PD, Plummer LN (2005) Geochemistry and the understanding of ground-water systems. Hydrogeol J 13(1):263-287. doi:10.1007/ s10040-004-0429-y

Goode DJ (1996) Direct simulation of groundwater age. Water Resour Res 32(2):289-296. doi:10.1029/95WR03401

Gumm LP, Bense VF, Dennis PF, Hiscock KM, Cremer N, Simon S (2016) Dissolved noble gases and stable isotopes as tracers of preferential fluid flow along faults in the lower Rhine embayment, Germany. Hydrogeol J 24(1):99-108. doi:10.1007/s10040-0151321-7

Habermehl MA (1980) The Great Artesian Basin, Australia. BMR J Aust Geol Geophys 5:9-38

Harrington GA, Cook PG, Herczeg AL (2002) Spatial and temporal variability of ground water recharge in central Australia: a tracer approach. Ground Water 40(5):518-527. doi:10.1111/j.1745-6584. 2002.tb02536. $\mathrm{x}$

Hart DJ, Bradbury KR, Feinstein DT (2006) The vertical hydraulic conductivity of an aquitard at two spatial scales. Ground Water 44(2): 201-211. doi:10.1111/j.1745-6584.2005.00125.x

Hendry MJ, Kelln CJ, Wassenaar LI, Shaw J (2004) Characterizing the hydrogeology of a complex clay-rich aquitard system using detailed vertical profiles of the stable isotopes of water. J Hydrol 293(1-4): 47-56. doi:10.1016/j.jhydrol.2004.01.010

Herczeg AL, Torgersen T, Chivas AR, Habermehl MA (1991) Geochemistry of ground waters from the Great Artesian Basin, Australia. J Hydrol 126(3-4):225-245. doi:10.1016/00221694(91)90158-E

Herczeg AL, Love AJ, Allan G, Fifield LK, Int Atom Energy A (1996) Uranium-234/238 and chlorine-36 as tracers of inter-aquifer mixing: Otway Basin, South Australia. In: Proc. Isotopes in Water Resources Management conference, vol 2. IAEA, Vienna, pp 23-133

Herczeg AL, Dogramaci SS, Leaney FWJ (2001) Origin of dissolved salts in a large, semi-arid groundwater system: Murray Basin, Australia. Mar Freshw Res 52(1):41-52. doi:10.1071/MF00040 
Hiscock KM, Rivett MO, Davison RM (2002) Sustainable groundwater development. Geol Soc Spec Pub 193:1-14. doi:10.1144/GSL.SP. 2002.193.01.01

Howe PE, Baird DJ, Lyons DJ (2008) Hydrogeology of the southeast portion of the Arckaringa Basin and southwest portion of the Eromanga Basin, South Australia, vol 13. Water Down Under, Adelaide, Australia

IESC (2014) Aquifer connectivity within the Great Artesian Basin, and the Surat, Bowen and Galilee basins: background review. Commonwealth of Australia, Sydney, Australia

Keppel M, Karlstrom KE, Love AJ, Priestley SC, Wohling D, De Ritter S (2013) Allocating water and maintaining springs in the Great Artesian Basin, vol I: hydrogeological framework of the western Great Artesian Basin. National Water Commission, Canberra, Australia

Keppel M, Jensen-Schmidt B, Wohling D, Sampson L (2015) A hydrogeological characterisation of the Arckaringa Basin. Government of South Australia, Dept. of Environment, Water and Natural Resources, Adelaide, Australia

Kipfer R, Aeschbach-Hertig W, Peeters F, Stute M (2002) Noble gases in lakes and ground waters. In: Porcelli D, Ballentine CJ, Wieler R (eds) Noble gases in geochemistry and cosmochemistry. Mineralogical Soc Am, Chantilly, VA, pp 615-700

Kleinig T, Priestley SC, Wohling D, Robinson NI (2015) Arckaringa Basin aquifer connectivity. Government of South Australia, Dept. of Environment, Water and Natural Resources, Adelaide, Australia

Konikow LF, Neuzil CE (2007) A method to estimate groundwater depletion from confining layers. Water Resour Res 43(7). doi:10.1029/ 2006wr005597

Kretschmer P, Wohling D (2014) Groundwater recharge in the eastern Anangu Pitjantjatjara Yankunytjatjara lands. Government of South Australia, Dept. of Environment, Water and Natural Resources, Adelaide, Australia

Larsen D, Gentry RW, Solomon DK (2003) The geochemistry and mixing of leakage in a semi-confined aquifer at a municipal well field, Memphis, Tennessee, USA. Appl Geochem 18(7):1043-1063. doi:10.1016/S0883-2927(02)00204-4

Love AJ, Herczeg AL, Armstrong D, Stadter F, Mazor E (1993) Groundwater-flow regime within the Gambier embayment of the Otway basin, Australia: evidence from hydraulics and hydrochemistry. J Hydrol 143(3-4):297-338. doi:10.1016/00221694(93)90197-h

Love AJ, Herczeg AL, Walker G (1996) Transport of water and solutes across a regional aquitard inferred from deuterium and chloride profiles Otway Basin, Australia. Isotopes in Water Resources Management (Proc. Symp. Vienna, 1995). IAEA, Vienna, pp 273 286

Love AJ, Herczeg AL, Sampson L, Cresswell RG, Fifield LK (2000) Sources of chloride and implications for ${ }^{36} \mathrm{Cl}$ dating of old groundwater, southwestern Great Artesian Basin. Australia Water Resour Res 36(6):1561-1574. doi:10.1029/2000WR900019

Love AJ, Wohling D, Fulton S, Rousseau-Gueutin P, De Ritter S (2013) Allocating water and Maintaining Springs in the Great Artesian Basin, vol II: groundwater recharge, hydrodynamics and hydrochemistry of the western Great Artesian Basin. National Water Commission, Canberra, Australia

Mahara Y, Habermehl MA, Hasegawa T, Nakata K, Ransley TR, Hatano T, Mizuochi Y, Kobayashi H, Ninomiya A, Senior BR, Yasuda H, Ohta T (2009) Groundwater dating by estimation of groundwater flow velocity and dissolved ${ }^{4} \mathrm{He}$ accumulation rate calibrated by ${ }^{36} \mathrm{Cl}$ in the Great Artesian Basin, Australia. Earth Planet Sci Lett 287:43-56. doi:10.1016/j.eps1.2009.07.034

Marty B, Dewonck S, France-Lanord C (2003) Geochemical evidence for efficient aquifer isolation over geological timeframes. Nature 425(6953):55-58. doi:10.1038/nature01966
Masoud M, Schumann S, Mogheeth SA (2013) Estimation of groundwater recharge in arid, data scarce regions: an approach as applied in the El Hawashyia basin and Ghazala sub-basin (Gulf of Suez, Egypt). Environ Earth Sci 69(1):103-117. doi:10.1007/s12665012-1938-y

McCallum JL, Cook PG, Dogramaci S, Purtschert R, Simmons CT, Burk L (2017) Identifying modern and historic recharge events from tracer-derived groundwater age distributions. Water Resour Res 53(2):1039-1056

McCutcheon SC, Martin JL, Barnwell TO Jr (1993) Water quality. In: Maidment DR (ed) Handbook of hydrology. McGraw-Hill, New York

McMahon T, Murphy R, Little P, Costelloe J, Peel M, Chiew F, Hayes S, Nathan R, Kandel D (2005) Hydrology of Lake Eyre Basin. Sinclair Knight Merz, Armadale, Scotland

Melloul AJ (1995) Use of principal components analysis for studying deep aquifers with scarce data-application to the Nubian sandstone aquifer, Egypt and Israel. Hydrogeol J 3(2):19-39. doi:10.1007/ s100400050056

Moya CE, Raiber M, Taulis M, Cox ME (2015) Hydrochemical evolution and groundwater flow processes in the Galilee and Eromanga basins, Great Artesian Basin, Australia: a multivariate statistical approach. Sci Total Environ 508:411-426. doi:10.1016/j.scitotenv. 2014.11.099

Myers T (2012) Potential contaminant pathways from hydraulically fractured shale to aquifers. Ground Water 50(6):872-882. doi:10.1111/j. 1745-6584.2012.00933.x

Neuman SP, Witherspoon PA (1972) Field determination of hydraulic properties of leaky multiple aquifer systems. Water Resour Res 8(5):1284-1298. doi:10.1029/WR008i005p01284

Neuzil CE (1994) How permeable are clays and shales. Water Resour Res 30(2):145-150. doi:10.1029/93wr02930

Post V, Kooi H, Simmons C (2007) Using hydraulic head measurements in variable-density ground water flow analyses. Ground Water 45(6):664-671. doi:10.1111/j.1745-6584.2007.00339.x

Richards J (2013) 2012 Groundwater annual environmental review and assessment of effects. Oz Minerals, Parkside, Australia

Sampson L, Wohling D, Jensen-Schmidt B, Fulton S (2012a) South Australia and Northern Territory Great Artesian Basin (Eromanga Basin) hydrogeological map, part 1. Dept. of Environment, Water and Natural Resources, South Australian Government, Adelaide, Australia

Sampson L, Wohling D, Jensen-Schmidt B, Fulton S (2012b) South Australia and Northern Territory Great Artesian Basin (Eromanga Basin) hydrogeological map, part 2. Dept. of Environment, Water and Natural Resources, South Australian Government, Adelaide, Australia

Sampson L, Wohling D, Keppel M, Jensen-Schmidt B (2015) South Australia Arckaringa Basin hydrogeological map, part 2. Dept. Environment, Water and Natural Resources, South Australian Government, Adelaide, Australia

Sanford WE, Aeschbach-Hertig W, Herczeg AL (2011) Preface: Insights from environmental tracers in groundwater systems. Hydrogeol $\mathrm{J}$ 19(1):1-3. doi:10.1007/s10040-010-0687-9

Shand P, Darbyshire DPF, Love AJ, Edmunds WM (2009) Sr isotopes in natural waters: applications to source characterisation and waterrock interaction in contrasting landscapes. Appl Geochem 24(4): 574-586. doi:10.1016/j.apgeochem.2008.12.011

SKM (2009) Prominent Hill Regional conceptual hydrogeological model. Prepared for OZ Minerals. SKM project no. VE23235, Sinclair Knight Merz, Armadale, Scotland

SKM (2010) Prominent Hill mine groundwater model update (PH5). Prepared for OZ Minerals. SKM project no. VE23146.600, Sinclair Knight Merz, Armadale, Scotland

Smerdon BD, Ransley TR, Radke BM, Kellett JR (2012) Water resource assessment for the Great Artesian Basin: a report to the Australian 
Government from the CSIRO Great Artesian Basin water resource assessment. CSIRO Water for a Healthy Country Flagship, Canberra, Australia

Smerdon BD, Smith LA, Harrington GA, Gardner WP, Piane CD, Sarout $J$ (2014) Estimating the hydraulic properties of an aquitard from in situ pore pressure measurements. Hydrogeol J. doi:10.1007/s10040014-1161-x

Suckow A (2013) System analysis using multitracer approaches. In: IAEA (ed) Isotope methods for dating old groundwater. International Atomic Energy Agency, Vienna, pp 217-244

Suckow A, Taylor A, Davies P, Leaney F (2016) Geochemical baseline monitoring. CSIRO, Canberra, Australia

Torgersen T, Clarke WB (1985) Helium accumulation in groundwater, I: an evaluation of sources and the continental flux of crustal ${ }^{4} \mathrm{He}$ in the Great Artesian Basin, Australia. Geochim Cosmochim Acta 49(5): 1211-1218. doi:10.1016/0016-7037(85)90011-0

Tóth J (2009) Gravitational systems of groundwater flow: theory, evaluation, utilization. Cambridge University Press, Cambridge

Trabelsi R, Kacem A, Zouari K, Rozanski K (2009) Quantifying regional groundwater flow between continental Intercalaire and Djeffara aquifers in southern Tunisia using isotope methods. Environ Geol 58(1):171-183. doi:10.1007/s00254-008-1503-x van der Kamp G (2001) Methods for determining the in situ hydraulic conductivity of shallow aquitards: an overview. Hydrogeol J 9(1):516. doi: $10.1007 / \mathrm{s} 100400000118$

Vidic RD, Brantley SL, Vandenbossche JM, Yoxtheimer D, Abad JD (2013) Impact of shale gas development on regional water quality. Science 340(6134). doi:10.1126/science.1235009

Walker GR, Cook PG (1991) The importance of considering diffusion when using carbon-14 to estimate groundwater recharge to an unconfined aquifer. J Hydrol 128(1):41-48. doi:10.1016/00221694(91)90130-A

Wang Y, Jiao JJ, Cherry JA, Lee CM (2013) Contribution of the aquitard to the regional groundwater hydrochemistry of the underlying confined aquifer in the Pearl River Delta, China. Sci Total Environ 461462:663-671. doi:10.1016/j.scitotenv.2013.05.046

Wohling D, Keppel M, Fulton S, Costar A, Sampson L, Berens V (2013) Australian initiative on coal seam gas and large coal mining: Arckaringa Basin and Pedirka Basin groundwater assessment projects. Government of South Australia, Dept. of Environment, Water and Natural Resources, Adelaide, Australia

Zilberbrand M, Rosenthal E, Weinberger G (2014) Natural tracers in Senonian-Eocene formations for detecting interconnection between aquifers. Appl Geochem 47:157-169. doi:10.1016/j.apgeochem. 2014.05.022 